\title{
COVID-19 and the Future of Microfinance: Evidence and Insights from Pakistan*
}

\author{
Kashif Malik $^{\dagger}$ Muhammad Meki ${ }^{\ddagger}$ Jonathan Morduch $^{\S}$ \\ Timothy Ogden ${ }^{\mathbb{I}} \quad$ Simon Quinn" $\quad$ Farah Said**
}

April 27, 2020

\begin{abstract}
The COVID-19 pandemic threatens lives and livelihoods, and, with that, has created immediate challenges for institutions that serve affected communities. We focus on implications for local microfinance institutions in Pakistan, a country with a mature microfinance sector, serving a large number of households. The institutions serve populations poorly-served by traditional commercial banks, helping customers invest in microenterprises, save, and maintain liquidity. We report results from 'rapid response' phone surveys of about 1,000 microenterprise owners, a survey of about 200 microfinance loan officers, and interviews with regulators and senior representatives of microfinance institutions. We ran these surveys starting about a week after the country went into lockdown to prevent the spread of the novel coronavirus. We find that, on average, week-on-week sales and household income both fell by about $90 \%$. Households' primary immediate concern in early April became how to secure food. As a result, $70 \%$ of the sample of current microfinance borrowers reported that they could not repay their loans; loan officers anticipated a repayment rate of just 34\% in April 2020. We build from the results to argue that COVID-19 represents a crisis for microfinance in low-income communities. It is also a chance to consider the future of microfinance, and we suggest insights for policy reform.
\end{abstract}

*We thank Ahmad Ayub, Fatima Khan, Lubna Marouf and Umer Zahid for invaluable assistance in this research. The research would not have been possible without the support of Syed Mohsin Ahmed, Shahzad Akram, Rashid Bajwa, Amjad Saqib, Mariam Shakir, Tahir Waqar, and Roshaneh Zafar. We thank Chris Woodruff for comments. The survey described in this paper was funded by the Financial Services for the Poor Initiative at Innovations for Poverty Action (IPA), sponsored by a grant from the Bill \& Melinda Gates Foundation. Morduch and Ogden gratefully acknowledge funding from the Mastercard Impact Fund. Ethical approval was granted by the University of Oxford Department of Economics Departmental Research Ethics Committee (reference ECON1A20-21-11). This paper is one of a number commissioned by the Oxford Review of Economic Policy in response to the COVID-19 pandemic. In due course they will be collected into an online-only issue of the journal, on 'The economics of the COVID-19 pandemic', to be published in July. Simon Quinn is currently serving as an Associate Editor of the Oxford Review of Economic Policy.

${ }^{\dagger}$ Department of Economics, Lahore University of Management Sciences

†Department of International Development and Oxford Centre for Islamic Studies, University of Oxford

${ }^{\S}$ Robert F. Wagner Graduate School of Public Service, New York University

IIManaging Director, Financial Access Initiative, New York University

"Department of Economics and Centre for the Study of African Economies, University of Oxford

** Department of Economics and Centre for Research in Economics and Business, Lahore School of Economics 


\section{COVID-19 and the future of microfinance}

The novel coronavirus presents a grave threat to human health. The lockdowns implemented in country after country, starting in March and April 2020, have been the first line of defence, limiting the spread of COVID-19 but coming at the cost of livelihoods. ${ }^{1}$ A question soon asked is: 'Save Lives or Save Livelihoods?' (Khawar, 2020). Connected to that question is another that receives less attention: How to save the institutions that people rely on for basic services? As livelihoods collapse in the wake of the lockdowns, local institutions also face what some have termed existential threats (Ogden and Bull, 2020).

We focus on microfinance institutions (MFIs). Microfinance institutions offer loans and saving accounts to low-income customers who lack easy access to traditional commercial banks. The liquidity and saving services can be particularly demanded during crises and, later, when owners of small businesses seek to re-capitalize. Yet as household incomes have collapsed with the imposition of lockdowns, borrowers' ability to repay loans has collapsed too.

We build insights from a series of interconnected surveys and interviews in Pakistan - the world's fifthmost populous country at over 200 million residents and home to a large, mature microfinance sector. We first document the immediate consequences of the lockdown, presenting rapid-response survey data collected in early April 2020. We then show how the challenges faced by households translate into challenges faced by the institutions that serve them, drawing on interviews with regulators, with the senior staff of microfinance institutions, and with loan officers.

The health crisis grew quickly in Pakistan, as in much of the world. The Government of Pakistan counted 53 confirmed cases of COVID-19 on 15 March. A month later, on 15 April, the cumulative count had risen to 6,528, a 51 percent jump from the week before. ${ }^{2}$ Unreported and unconfirmed cases

\footnotetext{
${ }^{1}$ See, for example, the policy response tracker of Hale and Webster (2020).

${ }^{2}$ By April 22, 2020, the official cumulative count had increased by another 61 percent to 10,513. Calculations are based on data accessed on April 23, 2020 from http://covid.gov.pk/stats/pakistan.
} 
likely mean that the spread was many times greater. ${ }^{3}$ Lockdowns (restrictions on all but 'crucial' economic and social activities) started in Sindh province on 14 March and then were extended to other regions.

We started surveys about a week after the country went into lockdown. The first sample comprises 507 microfinance customers from Punjab, Sindh, and Kashmir regions. About three-quarters are women, and their average age is 39. Business income makes up the bulk of their household income, and their microfinance loans are, on average, about US $\$ 300 .^{4}$ A second sample is made up of 500 individuals; they are slightly better-off than the first sample and mostly (92\%) men. Most have 'graduated' from microfinance borrowing (where their average loan size had been $\$ 450$ ).

Both samples experienced devastating week-on-week collapses of business sales and household income after the lockdown. The first sample experienced an $88 \%$ drop in average weekly household income (from $\$ 42$ to $\$ 5$ ) and the second experienced a $91 \%$ drop (from $\$ 58$ to $\$ 6$ on average). Their immediate concern became how to secure food. Workers in the informal sector, with little or no job protection, were hit particularly hard, and the findings here are similar to results reported in other studies. For example, Rahman and Matin (2020) report on phone surveys of almost 5,500 respondents in both urban and rural Bangladesh, following that country's lockdown on 26 March. They find a drop of about $80 \%$ in income among respondents living in urban slums, with respondents overwhelmingly requesting either food support or cash support. Similarly, Rutherford (2020) finds an average reduction of two-thirds of household income among 26 self-employed financial diarists in central Bangladesh. ${ }^{5}$

\footnotetext{
${ }^{3}$ On 17 April, the government reported that 92,548 tests had been completed in a population larger than 200 million people. (Data from http://covid.gov.pk/stats/pakistan, accessed 18 April, 2020.)

${ }^{4}$ Henceforth, we use \$ to refer to US\$, calculated using the USD-PKR exchange rate of 154 on March 1, 2020.

${ }^{5}$ See also Afridi et al. (2020) (who report on rapid-response data from 413 households in urban Delhi), Duflo and Banerjee (2020) (who refer briefly to a recent rapid-response survey in Karnataka, India), and Abi-Habib and Yasir (2020) (who report several individual stories of casual labourers in India). More generally, our work joins several recent empirical studies on the immediate economic effects of the coronavirus lockdown (for example, see Adams-Prassl et al. (2020) and Bick and Blandin (2020) on labour market effects, and Bartik et al. (2020) and Dai et al. (2020) on small businesses). These are just a small number of the many ongoing economic research projects on coronavirus; see, for example, https://www . eeassoc.or g/index.php?site=JEEA\&page=298\&trsz=299 and https: / cepr.org / content $/$ covid-economics -vetted-and-real-time-papers-0.
} 
The income collapse also meant that $70 \%$ of the sample of regular borrowers reported that they could not meet the required payment on their microfinance loans. Our survey of loan officers reveals the implications for lenders: February's average loan repayment rate of $98 \%$ fell to $81 \%$ in March (reflecting the lockdown that started in the third week of the month) and was predicted to fall to 34\% in April 2020.

The borrowers' inability to repay loans immediately put pressure on lenders' ability to repay their own investors and funders and to fund their on-going operations. The borrowers' short-term economic crisis thus produced a liquidity crunch for lenders. The institutions' survival will depend on the duration of the crisis, how much financial cushion the financial institutions have, the willingness of their own creditors to be patient and forgiving, steps taken by regulators and donors, and the ability and willingness of customers to eventually make good on their obligations.

Interviews with senior staff of microfinance institutions, loan officers and regulators lead to a series of insights.

First, 'microfinance' is a broad category. The sector is no longer made up predominantly of organizations that seek to replicate and build on Bangladesh's Grameen Bank. Instead, today, a variety of different kinds of microfinance organizations provide financial services in low-income communities. Some see themselves mainly as charitable organizations, charge zero interest or mark-up on loans, and draw on Zakat from the community and other charitable funding. ${ }^{6}$ Others pursue a combination of social and commercial goals, charging a modest mark-up and receiving funding from sources including international development institutions. A third category relies heavily on investment with a commercial focus, and the institutions primarily pursue profit like traditional banks. Policy addressed toward 'microfinance' needs to be specific to the type of institution.

\footnotetext{
${ }^{6}$ Zakat is an annual wealth tax that is a religious obligation in Islam, requiring individuals with assets above a certain threshold
} to donate $2.5 \%$ of their wealth to charitable causes. 
Second, the diversity of microfinance institutions extends to their regulation. This matters especially in this time of crisis. Who is regulated by whom shapes who is accountable to whom - and also who is in line for help. In Pakistan, 'microfinance banks' (MFBs) take deposits and are regulated by the State Bank of Pakistan (SBP), and tend to serve somewhat better-off customers. 'Microfinance non-bank financial companies' (NBFCs) are not allowed to hold deposits, and their regulation is relatively light. ${ }^{7}$ Most of the NBFCs were once NGOs, and they include organizations that serve relatively poor communities. The present crisis makes the trade-offs between levels of regulation and access to support from regulators much more explicit: the NBFCs are not connected to the State Bank of Pakistan, most likely the lender of last resort, ${ }^{8}$ yet they are the organizations serving the most vulnerable populations and are plausibly most in need of support.

Third, a basic principle of bank regulation is that serious oversight is needed for deposit-taking institutions but not for others. The idea is that deposit-taking institutions (like Pakistan's MFBs) hold the money of citizens, and the government has an interest in ensuring that the money will be available to the population when needed. A corollary explains why NBFCs are not regulated by the State Bank of Pakistan. One line of thinking is that if the NBFCs collapse, borrowers do not lose their money, since they hold deposits elsewhere. Instead, borrowers might even come out ahead, since the lender may be unable to collect loan obligations. But the crisis shows that this regulatory distinction provides an unreliable guide. Even microfinance institutions that do not take deposits need regulatory oversight, particularly with consumer protection in mind. The early days of the COVID-19 crisis in Pakistan reveal why such regulation (by the Securities and Exchange Commission of Pakistan) is so important. We document instances of problems with loan officers in which customers - who were in highly vulnerable positions - were left confused about their obligations and means of recourse. Industry efforts to promote self-regulation are laudable, but they are imperfect substitutes for real regulation with real

\footnotetext{
${ }^{7}$ NBFCs are regulated by the Securities and Exchange Commission of Pakistan (SECP).

${ }^{8}$ The State Bank of Pakistan actively monitors the liquidity position of MFBs, and has reported to us that there are no signs of liquidity problems as of mid-April 2020. In order to provide a buffer for MFBs to absorb liquidity schocks, the SBP requires them to hold a cash reserve ratio (CRR) of 5\% and a statutory liquidity ratio (SLR) of $10 \%$ of their deposits (consisting of both time and demand liabilities).
} 
teeth. ${ }^{9}$ Moreover, the idea that the collapse of lenders won't hurt borrowers ignores how important maintaining liquidity is in low-income economies.

Fourth, best practices in normal times can be bad practices during a crisis. One example is the way that loan officers are paid, sometimes with large incentives intended to motivate hard work and to maximize effort. In most MFIs, a significant proportion of the total income earned by loan officers is comprised of performance-related payments based on new loan disbursements and the repayment of existing loans (Pakistan Microfinance Network, 2019). Economists call these 'high-powered incentives', and they make sense when objectives are clear and those objectives are aligned with the best outcomes for communities. In normal times, they enhance the efficiency of organizations. But these are not normal times, and these circumstances may now call for 'low-powered incentives' in which loan officers are paid a steady income that is not closely tied to loan disbursements and collections. This lets loan officers focus on helping customers in the most effective ways without having to worry about their own earnings. ${ }^{10}$ With high-powered incentives still in place, the data we have collected suggests that some loan officers are still demanding repayments from customers, even when senior staff have established policies creating repayment moratoriums.

Fifth, microfinance still relies on face-to-face transactions, despite the rapid growth of digital financial services. Loan officers, for example, require personal meetings with clients, both to make loans and to collect repayments. It is also true of microfinance transactions involving mobile money whose success depends upon the widespread in-person participation of agents. Though not nearly as obvious, microfinance relies on the face-to-face transactions that are part and parcel of its customers' businesses. The business model assumes a large set of viable microenterprises, most of which, whether in services or in small-scale manufacturing, also depend on face-to-face contact between firms and their clients. The 'digital revolution' is bringing transformative change around the world, but it will not remove the place

\footnotetext{
${ }^{9}$ In Pakistan, NBFC microfinance institutions must follow regulations and reporting requirements under SRO 279(I)/202O dated 31.3.20. An amemdnent to clause 28 is relevant as it addresses consumer protection, including grievance redressal mechanisms for microfinance borrowers. One well-established example of self-regulation is the certification program of the SMART Campaign. See https: //www. smartcampaign.org/.

${ }^{10}$ For a discussion of incentives in microfinance, see Armendáriz and Morduch (2010).
} 
of face-to-face, personal interaction.

Sixth, microfinance relies on trust between institutions and customers. Some call this 'social capital' or 'organizational capital'. Such 'capital' can be difficult to build up and is costly to lose. Institutions need to make sure that they are preserving their social and organizational capital, recognizing that how institutions treat their customers during a crisis may be more important in shaping trust than how they treat customers during normal times. Communication should be transparent, and loan officers should be given incentives to put customers' needs first. Microfinance institutions need to limit their losses, but for their struggling customers microfinance debt obligations may serve to heap further misery upon an intolerable situation. Some microfinance institutions have taken steps to provide charitable resources during the crisis. Some loans may need to be written off. Such write-offs, while obviously preferable for clients, would have serious implications for the viability of microfinance institutions.

Helping microfinance institutions survive the crisis - which will require concerted action by investors, regulators, and other private and public actors - is needed to ensure that customers will have access to the resources they will need to manage liquidity when the pandemic is under control. Emergency liquidity facilities and recapitalization will be needed to allow microfinance institutions of all kinds to forbear or forgive current loans. Supporting microfinance should be a sustained concern as regulators and central bank authorities move to stabilize the entire financial sector. Most microfinance clients are from relatively poor segments of the community and are working hard to move forward. A collapse of the microfinance sector risks pushing those communities backward. 


\section{Context and background}

\subsection{Microfinance in Pakistan}

Microfinance has grown rapidly in Pakistan over the last decade. The number of active borrowers more than doubled from 2014 to 2019 , increasing from 2.8 million in 2014 to 7.3 million in $2019 ;{ }^{11}$ over the same time period, the gross loan portfolio increased by $400 \%$, from $\$ 400$ million in 2014 to $\$ 2$ billion in 2019 (Pakistan Microfinance Network, 2019, 2020). Nearly half of the active borrowers are women and $53 \%$ reside in rural areas. The average loan principal amount is approximately $\$ 300$, typically to be repaid in 12 months, and at interest rates ranging from 0 to $40 \%$. Microfinance clients in Pakistan are typically relatively poor, but not poor enough to be eligible for many targeted poverty-reduction programmes. $^{12} 13 \%$ of the loans in Pakistan were provided at $0 \%$ interest, predominately by a single large MFI (Basharat and Sheikh, 2019). The sector has maintained remarkably low default rates, with write-offs less than $1 \%$ of the gross loan portfolio. ${ }^{13}$

There are 46 registered microfinance providers in Pakistan, and these fall into two key categories: microfinance banks (MFBs, of which there are 11), and non-bank microfinance companies (NBFCs, of which there are 35). The key distinction concerns deposits: MFBs are permitted to accept deposits, whereas NBFCs are not. ${ }^{14}$ For this reason, MFBs are regulated by the State Bank of Pakistan (SBP), whereas NBFCs are regulated by the Securities and Exchange Commission of Pakistan (SECP). ${ }^{15}$

\footnotetext{
${ }^{11}$ In comparison, as of October 2019, the number of active borrowers in India was 43.6 million and in Bangladesh 12.4 million (MIX, 2019).

${ }^{12}$ For example, the Benazir Income Support Programme is available for households with a poverty score below 16.17, and the new 'Ehsaas' emergency grant is available for households with a score between 16.17 and 20. Typically, microfinance clients have a poverty score between 35 and 60 . There is just one large microfinance institution that specifically targets as clients households with poverty scores between 16.17 and 35 .

${ }^{13}$ Portfolio at risk (over a 30 day period) has also been low, at about $1.6 \%$ of the gross loan portfolio (Pakistan Microfinance Network, 2019). Of all loans, approximately $70 \%$ are structured as individual-liability.

${ }^{14}$ The NBFCs can further be divided into non-bank microfinance institutions (of which there are 25), and the Rural Support Programmes (of which there are 10). Rural Support Programmes differ from other NBFCs in that they have a purely rural focus; like other NBFCs, they are not permitted to accept deposits.

${ }^{15}$ On the regulation of MFBs by the SBP, see the Prudential Regulations for Microfinance Banks (2014) and the Financial Consumer Protection Circular (2014). On the regulation of NBFCs by the SECP, see the amendment to the Non-Banking Finance Companies (Establishment and Regulation) Rules (2003) and the Non-Banking Finance Companies and Notified Entities Regulations, 2008.
} 
Together, MFBs serve $49 \%$ of active borrowers, and are responsible for about $70 \%$ of the gross loan portfolio; about $80 \%$ of the total outreach of the sector can be attributed to a combination of eight MFBs and two NBFCs. MFBs' primary source of funding is public deposits, with borrowing constituting less than $10 \%$ (borrowing is mostly from local banks and development finance institutions). About $75 \%$ of funds for NBFCs come from debt, provided mainly from the apex funding agency, the Pakistan Microfinance Investment Company (PMIC); owing to strict guarantee requirements and currency risks, local commercial banks loans and international loans comprise a relatively small proportion of total debt in the sector (Pakistan Microfinance Network, 2019, 2020; Basharat and Sheikh, 2019). ${ }^{16}$

\subsection{The regulatory response to COVID-19}

Pakistan confirmed its first two cases of COVID-19 on 26 February 2020 (Shahid, 2020). The subsequent lockdowns were implemented on a region-by-region basis: Sindh announced a lockdown on 14 March, Azad Jammu and Kashmir on 16 March, and Punjab and Balochistan on 23 March. ${ }^{17}$ By the start of April, all educational institutions, shopping malls, public transport and entertainment venues had been closed across the country; religious and social congregations were banned and only essential shops (grocery and medical stores) were allowed to open (under restricted hours). On 13 April, the federal cabinet approved steps to ease the lockdown, to allow workers in construction and skill-related services (such as tailors, hairdressers and repairmen) to return to work. At the time of writing, restrictions are due to remain in effect until at least 30 April.

The State Bank of Pakistan and the Securities and Exchange Commission announced regulatory relief for all microfinance institutions at the end of March 2020, allowing flexibility in adhering to internal financial reporting standards, and encouraging them to defer borrowers' obligations to repay loan

\footnotetext{
${ }^{16}$ PMIC is a national-level apex institution that we also interviewed as part of our surveys, and which was founded by the Pakistan Poverty Alleviation Fund (PPAF), Karandaaz Pakistan and Germany's development bank KfW, and now provides financing for a number of microfinance institutions in Pakistan.

17 The lockdown in Sindh was implemented under Order SO(3-1)/HD/8-1/(04)/2020-Corona and SO(J-1)/HD/8-1(04)/2020Corona, under the Sindh Epidemic Diseases Act 2014. The lockdown in Azad Jammu and Kashmir was implemented under the Pandemic Diseases Control Act 1981. The lockdown in Punjab was implemented by a special order (NO(IS-III)11/2004) under section 144 of the national Code of Criminal Procedure 1898. The lockdown in Balochistan was implemented by special order (NOSO(Judl:)8(31)2020/545-630) under Section 144 of the Code of Criminal Procedure 1898.
} 
principal by one year (upon request from clients), while continuing to collect interest payments. ${ }^{18} \mathrm{We}$ discuss these policies in detail in the appendix.

\section{Rapid-response phone surveys in Pakistan}

To measure the impacts of these lockdowns, we conducted rapid-response phone surveys of microenterprises, loan officers and microfinance institutions. Our surveys of microenterprises and of loan officers followed broadly a similar structure: we used trained enumerators, making phone calls (from their homes), to ask a short list of closed quantitative questions. Previous experimental evidence on phone surveys supports the general viability of this approach for interviewing microenterprises in a low-income context (Garlick et al., 2019). These interviews were conducted in Urdu, and were complemented by follow-up interviews of selected respondents by our Pakistan-based authors (Kashif Malik and Farah Said). For senior representatives of microfinance institutions, we adopted a semi-structured approach, with phone interviews conducted by one or more of the co-authors (jointly with a research assistant). In this section, we briefly describe each of the samples.

We surveyed just over 1,000 microenterprise owners from two of the largest and most prominent microfinance institutions in Pakistan; half of the sample was drawn from a general population of microfinance borrowers with an outstanding loan, while the other half were 'graduated borrowers' (with whom members of our research team have worked in a previous project that provided expanded finance for their business). We decided to draw from these two separate sampling frames in order to improve our coverage across both smaller and somewhat larger microenterprises.

\footnotetext{
18 The State Bank announcement was made on 26 March 2020, and the Securities and Exchange Commission released their policy four days later. One slight nuance in the policy, which was raised as a concern in some MFI interviews, was that the debt relief applies only to loans that were non-delinquent as of February 2020. By not extending the relief to loans that were previously categorised as non-performing (many of which were still generating partial repayments), this negatively affects profitability as these technically non-performing loans (NPL) gradually move across 'NPL buckets' (from '30 days overdue' to '60 days overdue', and so on).
} 
Microfinance sample A (Regular microfinance clients): We generated a random sample from a large administrative list of current microfinance borrowers. We selected those who had received 'enterprise loans', and we stratified by gender, region, rural-urban split, and size of loan (the mean loan size was \$304 and median \$260). Our final surveyed sample consists of 507 borrowers, $77 \%$ of whom were from Punjab province, $14 \%$ from Sindh and 9\% from Kashmir. 72\% of respondents were female, with an average age of 39 years. All respondents confirmed that they were running a business, with the majority being single-person microenterprises (less than 5\% reported that they have an employee working in the business). The most popular business sectors were professional services, which includes schools, photographers and cleaning businesses (25\%), sewing and tailoring businesses (15\%), general retail shops, kiosks and hawkers (10\%), construction (9\%) and retails shops selling fabric and garments $(6 \%) .{ }^{19}$ In the two weeks prior to the COVID-19 lockdown, mean microenterprise sales for this sample were $\$ 35$ per week (with a median of \$32), and the mean of total household income from all sources (including income from wages, casual labour) in the week before the lockdown was $\$ 42$ (median $\$ 39$ ).

Microfinance sample B (Graduated borrowers): Sample B consisted of microenterprise borrowers who had graduated from loans of $\$ 450$ and previously participated in a field experiment where a subset were randomly offered financing of up to $\$ 1,900$ to expand their business with a fixed asset. ${ }^{20}$ This sample is predominantly male (only $8 \%$ female), with an average age that is almost identical to sample A (38 years), ten years of business experience, seven years of schooling, an $82 \%$ literacy rate and coming from households with on average six members, of which two earn some form of income.

The most popular business sectors were rickshaw driving (25\%), professional services, which includes schools, photographers and cleaning businesses (25\%), sewing and tailoring (12\%), food and drink

\footnotetext{
${ }^{19}$ More generally, the sectoral breakdown of active Pakistani microfinance borrowers across the whole country is as follows (Pakistan Microfinance Network, 2019): livestock and poultry (27\%), trade (25\%), agriculture (16\%), manufacturing and production $(6 \%)$, services $(9 \%)$ and other, including housing, $(18 \%)$. In our sampling strategy, we intentionally excluded agriculture and livestock due to their unique business dynamics and the resulting 'bullet' loans that only require one payment at the end of the loan period, for example at harvest time or during the religious festival period when animals are slaughtered.

${ }^{20}$ We therefore have much more detailed baseline data for this sample, from the earlier project. Note that these respondents did not necessarily have loans outstanding, as the previous project was completed two years earlier (but their responses reveal that $45 \%$ were in fact borrowing from the MFI).
} 
(7\%) and general retail shops, kiosks and hawkers (10\%). Microenterprises in this sample were less likely to be single-person operations, with $27 \%$ having at least one paid employee (compared to less than $5 \%$ in sample A, with the difference statistically significant at the $1 \%$ level). In the two weeks prior to the COVID-19 lockdown, mean microenterprise sales for this sample of graduated borrowers was approximately two-thirds greater than that of sample A, at \$55 per week (with a median of \$49) (a difference that is statistically significant at the $1 \%$ level). The mean of total household income from all sources in the week before the lockdown was $\$ 58$ (median $\$ 52$ ), which is approximately $40 \%$ greater than that of sample A.

Survey 2 (Microfinance loan officers): We interviewed 200 microfinance loan officers from three of the largest MFIs in Pakistan (including the two MFIs from which we drew our microenterprise sample). Loan officers were drawn from across the whole country, with a wider geographical spread than the sample of clients and microenterprises.

Survey 3 (Senior representatives of microfinance institutions and regulators): We conducted semi-structured interviews with senior representatives of 17 microfinance institutions (in 16 of these cases, it was directly with the CEO), and with the Pakistan Microfinance Network (the national association for the microfinance industry), the Pakistan Microfinance Investment Company (an apex institution that funds many microfinance institutions), the Securities and Exchange Commission and the central bank (the State Bank of Pakistan). Our sample of microfinance institutions included a mix of non-bank financial companies and microfinance banks, and a range of different institutional sizes, from small organizations providing microfinance as part of multi-dimensional social services, to larger providers with many active borrowers across the country. Our sample included the top five microfinance institutions in Pakistan. 


\section{Impacts of the COVID-19 lockdown}

In this section, we use our survey data to document the impacts of the COVID-19 lockdown. We summarise impacts on microenterprise sales, household income and repayment rates; to do this, we draw on the surveys from microenterprises and from loan officers. We then report on the views of those same microenterprises and loan officers about assistance required. Finally, we turn to our surveys with MFI leaders and regulators.

\subsection{Impacts on microenterprise sales}

Figure 1 illustrates the impact of the COVID-19 lockdown on microenterprise sales, plotting sales in the week after the lockdown against sales in the week before the lockdown, for both sample A (regular borrowers) and sample B (graduated borrowers); we also present a graph with loan officer reports of the impact on sales for their 'typical' client. Each figure also presents a 45-degree line and an OLS regression line (imposing a zero intercept). The results are stark: a dramatic fall in week-on-week sales. For sample A, weekly sales fell by $91 \%$ on average, from a mean of $\$ 33$ to a mean of $\$ 3$. Sample B experienced a $93 \%$ decline on average (not statistically different from that for sample A), from a pre-lockdown mean of $\$ 52$ to $\$ 4$ after the lockdown. ${ }^{21}$ Finally, to get an alternative perspective on the impact of the crisis on microenterprise performance, we asked loan officers to think about (and name) a 'typical' client, for whom we then asked them to estimate the pre-lockdown and post-lockdown sales. Results are generally consistent with the numbers reported by clients in the microenterprise survey. ${ }^{22}$ Loan officers reported that their typical client experienced a decrease in sales of $83 \%$.

There is substantial effect heterogeneity within each sample: in particular, $86 \%$ of sample A and $87 \%$ of sample B experienced a 100\% decrease in business sales (i.e. a complete shutdown of their business).

\footnotetext{
${ }^{21}$ One possible concern with Figure 1 is that the week immediately prior to the lockdown may have been an unusual one either because customers were deciding prematurely to stay at home, or because customers were accelerating purchases in anticipation of the lockdown. In Figure 6 (in the appendix), we compare sales in the week before the lockdown to sales in the week preceding that; we find that the relationship was remarkably stable, with the best fit lying close to the 45-degree line.

${ }^{22}$ It should be noted that loan officers do not map directly to microenterprises, in that we did not attempt to match them to microenterprise's regions; nonetheless, this provides a useful piece of information, and demonstrates that loan officers do have a reasonably good sense of clients' performance both in absolute terms and in terms of the impact of the lockdown.
} 


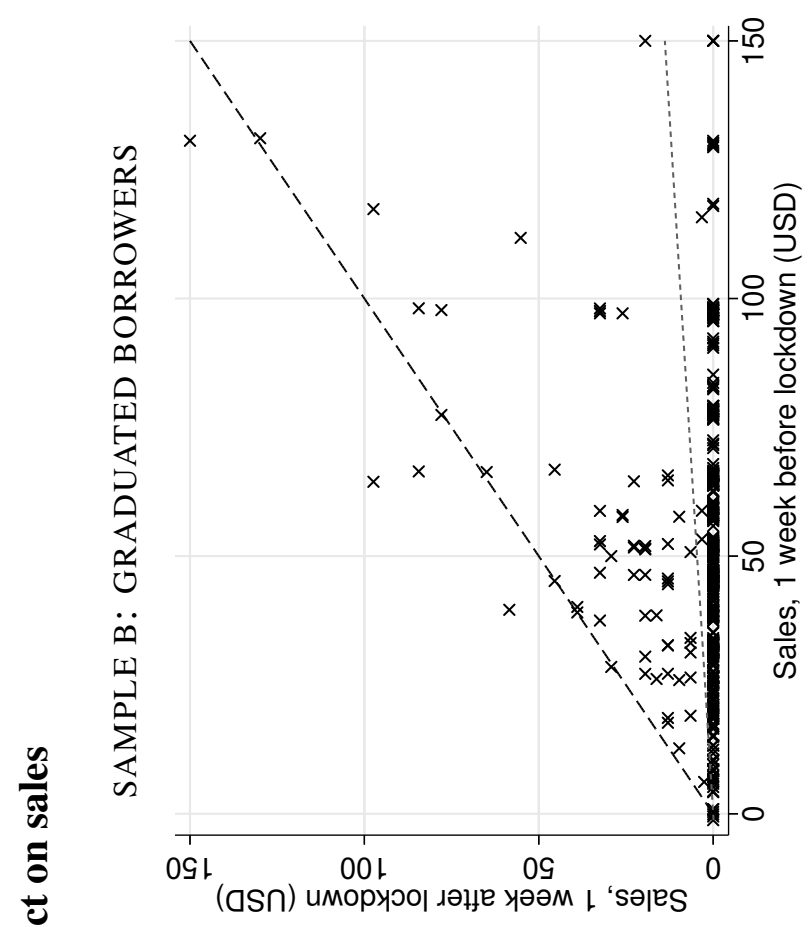

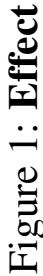
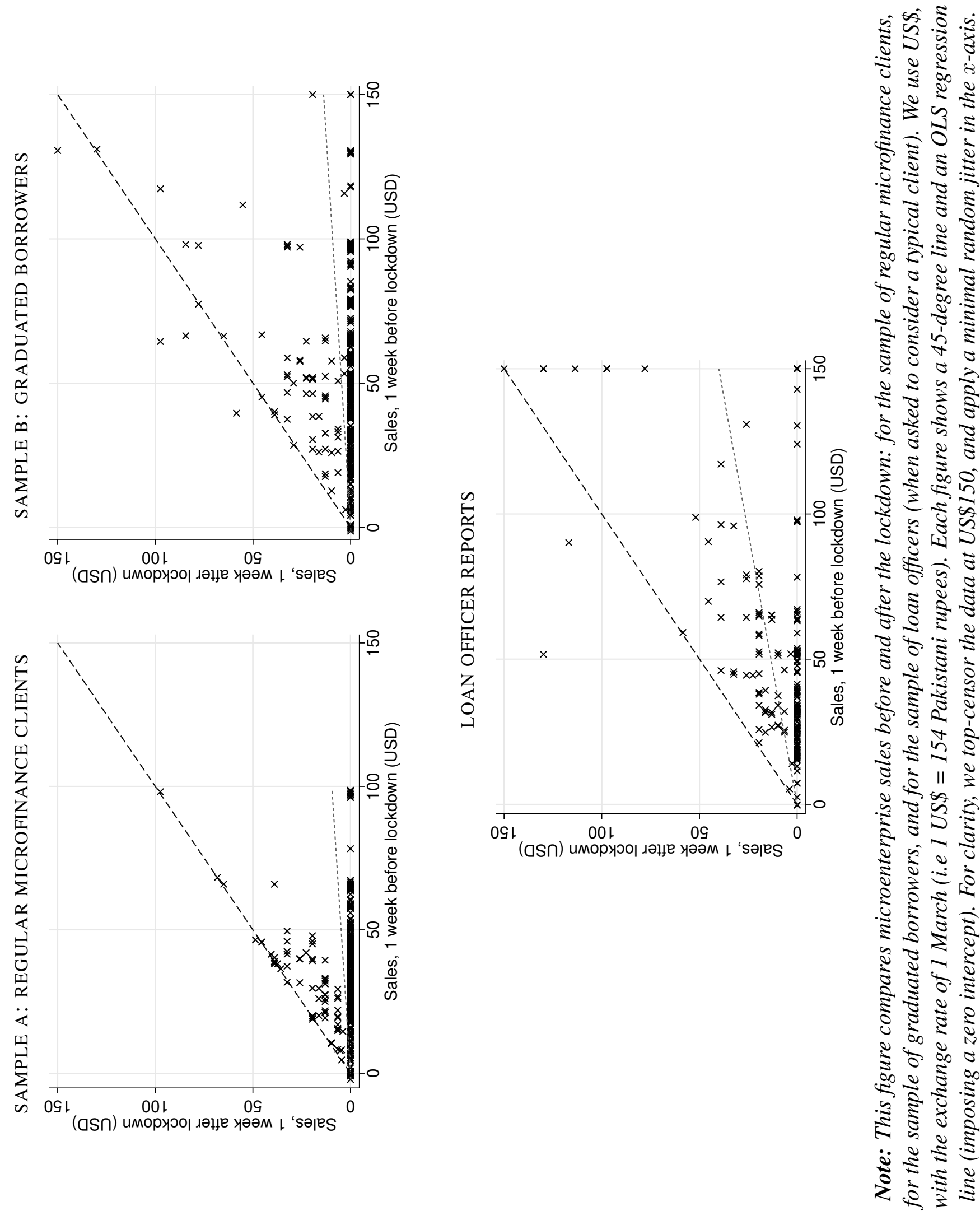
To further explore the types of microenterprise that experienced a complete shutdown, we created a dummy variable for having experienced a $100 \%$ decrease in sales; we then regressed this on demographic variables and business characteristics. We find - unsurprisingly - that businesses selling food or operating general retail stores and kiosks were less likely to experience a complete shutdown. ${ }^{23}$ We also find that female-run businesses were 8 percentage points more likely to experience a $100 \%$ decrease in business revenue than those run by men, even after controlling for sector and MFI fixed effects (a result that is statistically significant with $p=0.034$ ). This highlights a potentially important gender dimension to vulnerability as a result of the pandemic - something that comes across strongly in our qualitative interviews, particularly with loan officers.

We also asked all respondents a more general question about the major concerns they had relating to their business. The overwhelming concern (reported by 93\% of respondents, and not differing by sample) related to the ability to open their business if a lockdown persisted, which is consistent with the large share of businesses that experienced a complete shutdown. Other frequently cited concerns were the impact of the crisis on their suppliers (28\%), the loss of their client base (19\%), the long-term impact of the crisis on the income of those clients (17\%), and their ability to pay their bills, invoices, expenses and wages $(11 \%)$. Most of these concerns were shared by both samples and in similar frequencies, although graduated borrowers were much more likely to cite a concern about having to fire workers (16\% in sample B compared to $1 \%$ in sample A, with the difference statistically significant at the $1 \%$ level), which is unsurprising given that they were much more likely to have employees in the first place. Graduated borrowers were also more concerned about losses from trade credit that they had extended to clients (only $3 \%$ were worried about this in sample A, compared to $13 \%$ in sample B, with the difference significant at the $1 \%$ level). Focusing only on microenterprises that reported having employees, again the most cited concern was business closure in an extended lockdown (97\%), followed by much greater concerns about having to fire workers and about supply chain disruptions (both 53\%, and statistically different from the non-employer sample, at the $1 \%$ level).

\footnotetext{
${ }^{23}$ Specifically, microenteprise owners running a general retail store or kiosk and those running a food business were respectively 45 percentage points and 33 percentage points less likely to have reported a $100 \%$ decrease in their sales from the week before the lockdown to the week after.
} 


\subsection{Impacts on household income}

We next consider the impact of the lockdown on total household income from all sources. In short, this largely mirrors the impact on business sales; this implies - perhaps unsurprisingly - that there was no offsetting of the impact on sales with income from other sources such as wages, causal labour or transfers. Figure 2 presents the results graphically, plotting total household income in the week after the lockdown against total income in the week before the lockdown, for both the regular borrower sample and graduated borrowers. Sample A experienced an $88 \%$ average decrease in total income, from a mean of $\$ 42$ per week to a mean of $\$ 5$. Sample B experienced a $91 \%$ decline on average (not statistically different from that for sample A), from a pre-lockdown mean of $\$ 58$ to $\$ 6$ after the lockdown. Again, these averages mask the fact that $81 \%$ of sample A and $82 \%$ of sample B experienced a $100 \%$ decrease in total household income (which is marginally less than the $87 \%$ who experienced a $100 \%$ decrease in business sales).

A further question asked respondents whether they were worried about the effects of coronarvirus on their household's economic situation, including their ability to meet the household's expenditure needs. 9\% stated that they are worried and 91\% stated that they are very worried, with no difference in those proportions across samples. Loan officers were also asked if they were worried about the effects of the coronavirus on their clients' economic situation and ability to meet expenditure needs; $13 \%$ said that they were worried and $87 \%$ said that they were very worried. A further question asked them what specifically they were worried about for their clients; $40 \%$ said that their main worry was how clients could continue their business operations.

While we were completing this research, a third Pakistani MFI conducted a phone survey of 1,090 of its own borrowers. Their results confirm the trends that we found in our own survey. Their survey shows $90 \%$ of respondents reporting reductions in household income, with clients reporting substantial concerns about their ability to sustain their households. In the survey, $22 \%$ of respondent households say that they can sustain themselves only for another week, $18 \%$ say that they can sustain themselves 


\section{Figure 2: Effect on household income}

SAMPLE A: REGULAR MICROFINANCE CLIENTS

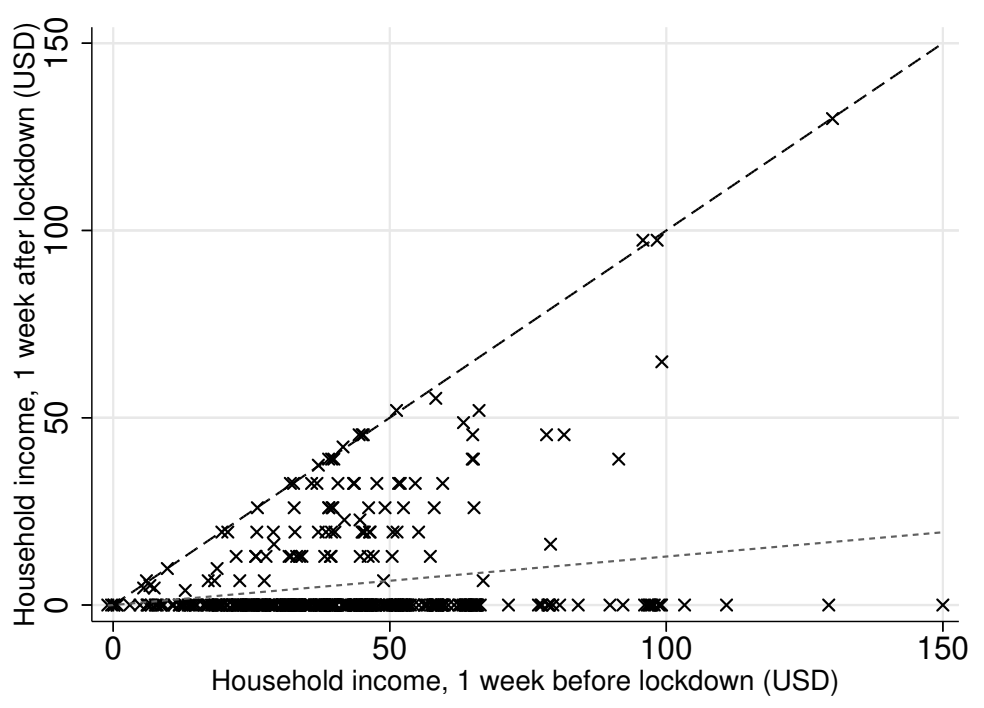

SAMPLE B: GRADUATED BORROWERS

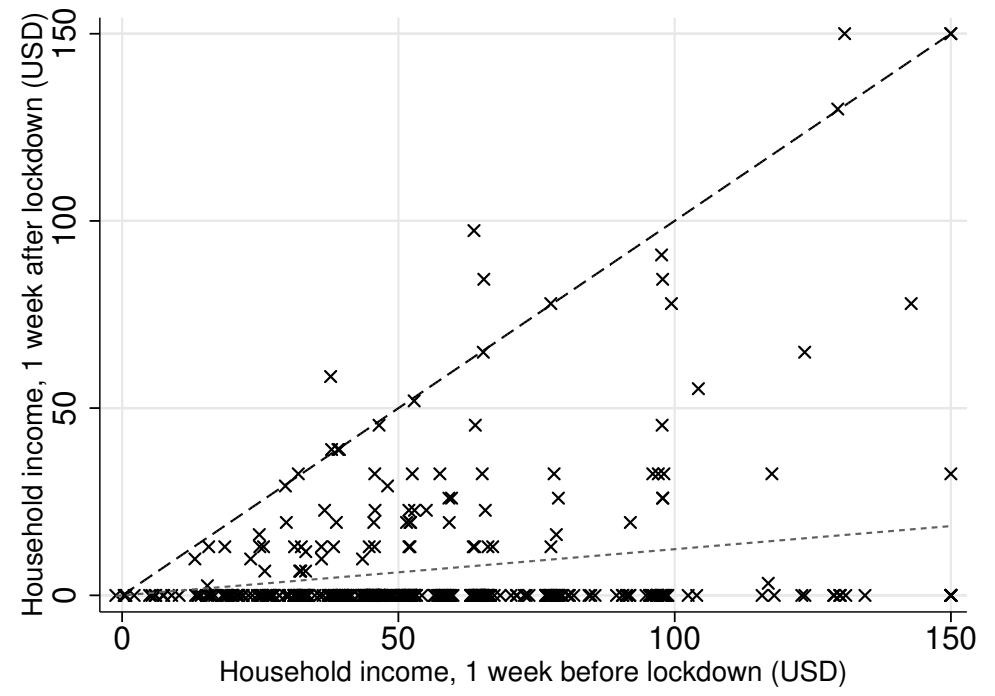

Note: This figure compares microenterprise household income before and after the lockdown: for the sample of regular microfinance clients, and for the sample of graduated borrowers. We use US\$, with the exchange rate of 1 March (i.e 1 US\$ = 154 Pakistani rupees). Each figure shows a 45-degree line and an OLS regression line (imposing a zero intercept). For clarity, we top-censor the data at US\$150, and apply a minimal random jitter in the $x$-axis. 
only for another 15 days, and $21 \%$ say that they can sustain themselves only for a month. ${ }^{24}$

\subsection{Impacts on loan repayments}

Figure 3 illustrates the impact of the lockdown on the ability of clients to meet their required repayments. The top graph shows the answers from microenterprise respondents. Microenterprise owners were first asked if they currently had any outstanding MFI loan; ${ }^{25}$ unsurprisingly, $97 \%$ of sample A had an outstanding loan, while $45 \%$ of graduated borrowers had an outstanding loan. ${ }^{26}$ Those who did have an outstanding loan were asked whether they would be able to pay back their scheduled microfinance loan payment next month, and - if not - what percentage they could pay. Only $30 \%$ of sample A stated that they were able to pay back the full monthly payment due on the loan, with the comparable number in the graduated borrower group being 23\%. Almost no borrowers suggested that they were able to repay their loan partially; this may reflect the practical reality that MFIs do not typically offer a mechanism for part-repayment. ${ }^{27}$

We also asked loan officers what the repayment rates were for their loan portfolios in February, March and April. The average repayment rate in February was 98\%, decreasing to $81 \%$ in March (which partially reflects the effect of the lockdown in the third week of the month), and significantly decreasing to 34\% predicted in April. As described in Section 4.5, these numbers are consistent with the predictions given by CEOs on their overall portfolio repayment rates. The second panel of Figure 3 graphically illustrates the sharp expected month-on-month decrease, plotting the repayment rate in March against the expected repayment rate in April.

More generally, we asked loan officers what worried them most about the impact of coronavirus on

24 These are our calculations based on anonymized data from the MFI.

25 We also asked if they had any informal loan, and only $1 \%$ stated that they did.

26 This does not refer to the loan in the earlier separate project; that loan was repaid prior to this study.

${ }^{27}$ See Section 4.5 for discussion of the most common interest rate calculation methodolgy implemented by MFIs, which is based on a 'declining balance' structure that leads to a fixed monthly payment (with month-on-month variation in the proportion that is due to interest and principal); partial repayment of principal would require a recalculation of the payment schedule, which - based on our intervews with MFIs - presents non-trivial implementation challenges, especially when accepting repayments through payment collection agencies. 
Figure 3: Effect on loan repayments
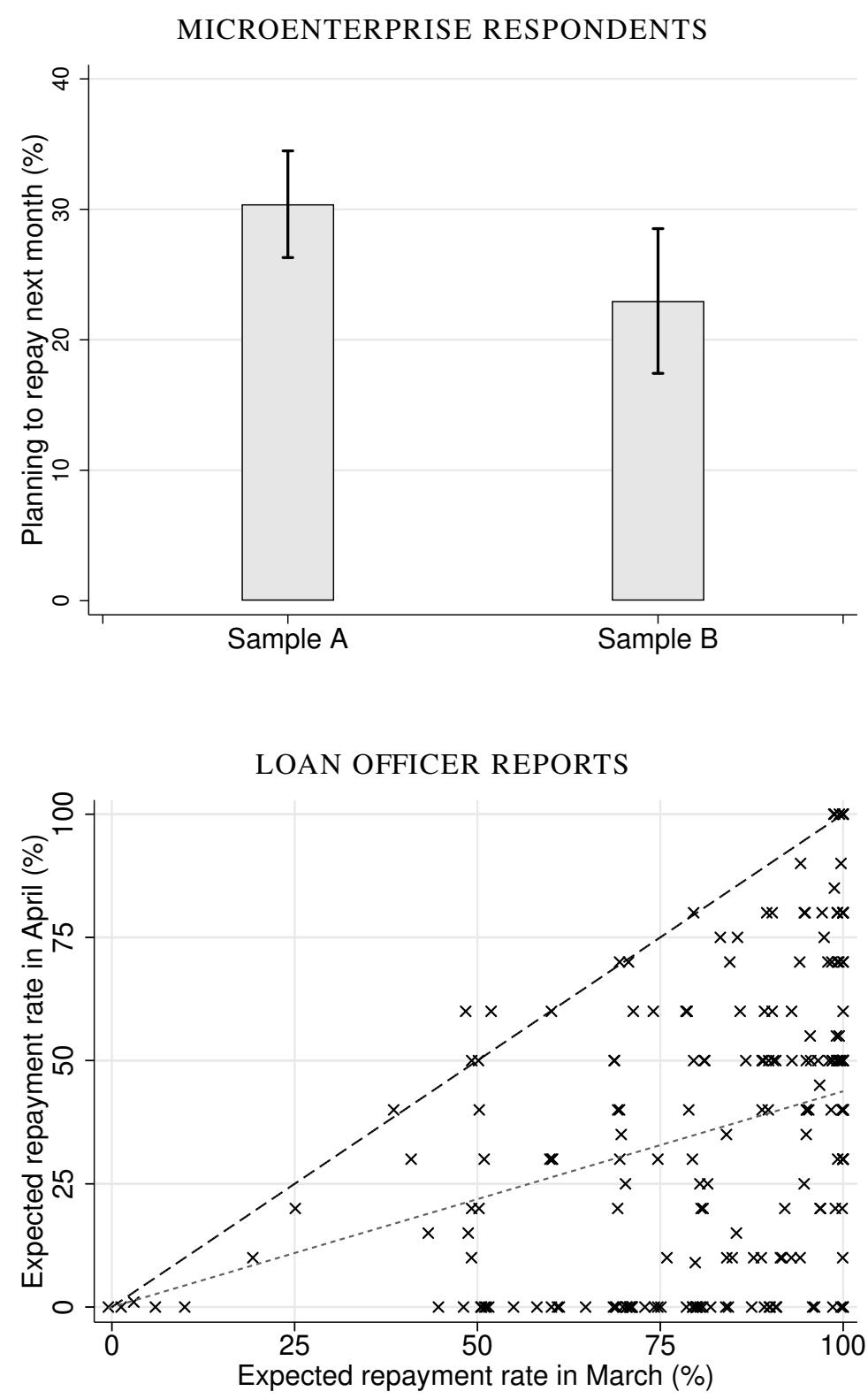

Note: This figure shows the proportion of microenterprise respondents who anticipate making repayments for the next month (with 95\% confidence intervals), for the sample of regular microfinance clients ('Sample A') and for the sample of graduated borrowers ('Sample B'). We also show loan officers' expected repayment rates, for March and April. This scatterplot shows a 45-degree line and an OLS regression line (imposing a zero intercept); for clarity, we apply a minimal random jitter in the $x$-axis. 
their organisation; $38 \%$ cited non-repayment of loans as their biggest worry, $28 \%$ said that it was their ability to collect repayments, and $23 \%$ mentioned the challenge in staying connected with people (either with their managers or clients). The next question asked them in more detail what worried them the most about the impact on their loan portfolio; $48 \%$ said that they were most worried about borrowers paying less than required, $20 \%$ were most worried about borrowers completely stopping the repayment of their loans, $11 \%$ said they were most concerned about their own performance evaluation, and $5 \%$ said that their biggest worry was that clients might shift to other MFIs who are providing non-financial support, such as food hampers, masks and soap (a concern shared by some MFI leaders that we interviewed). Interestingly, only $1 \%$ reported their biggest worry was that clients would completely leave the area; this is consistent with our finding in the microenterprise survey that, since the lockdown was announced, only $1 \%$ of respondents reported that they or any other member of their household had migrated to another part of Pakistan.

We asked both microfinance borrowers and loan officers whether the institution had reached out to borrowers to offer debt rescheduling or repayment flexibility. We find that - despite many MFI CEOs informing us that their official policy was to allow debt restructuring for all borrowers (see Section 4.5) $-96 \%$ of clients stated that they have not been contacted by the MFI to offer repayment flexibility, with no big difference between samples. This contrasts starkly with the $60 \%$ of loan officers who stated that they had offered repayment flexibility to their clients, or that they were intending to do so.

\subsection{Recommendations from microenterprises and loan officers}

We asked in several different ways about assistance and support. First, we asked about stress. Participants reported on a scale of 1 to 10 how stressed they were in various domains, with 10 representing most stressed. As illustrated in Figure 4, reported stress levels were very high across both samples and for all categories. Average reported stress levels were 8.0 for stress about respondent's own health or that of family members, 7.7 for stress about the social distancing restrictions in place, and 7.9 for stress about transport restrictions. Stress about food shortages was highest, at 8.4 on average (and statistically 
greater than all other measures, at the $1 \%$ level). Loan officers reported slightly lower stress levels for themselves, though still not low: 5.0 on average for food, 6.2 for health, 5.0 for social distancing measures and 6.5 for transportation restrictions. Loan officers also report moderate levels of stress for their own income (average of 5.3).

In qualitative open-ended questions at the end of the survey, loan officers expressed feeling more stress than they reported in the 'formal survey questions'. In particular, the qualitative assessments emphasize that morale was very low among loan officers, who were often facing multiple pressures: (i) local authorities pressuring them not to travel and to close down their offices (despite the fact that they were permitted to continue operations as 'essential staff'); (ii) client relationships being strained (particularly when their actions were compared to other organisations that were handing out aid and food packages); and (iii) particular challenges faced by female loan officers, who found it very difficult to move around with no public transport.

Second, microenterprise owners were asked a general question about what would most help them get through the crisis. As summarized in Figure 5, the overwhelming majority of graduated borrowers said it was a donation: $51 \%$ asking for cash donations, and $9 \%$ saying that they needed food donations or a new loan for consumption. Corresponding responses from regular borrowers were $26 \%$ suggesting cash donations and $13 \%$ asking for food donations. These responses are consistent with anecdotal evidence we obtained from the field, and from the senior management surveys, that many low-income individuals who had been living 'hand to mouth' are likely to face severe food shortages due to substantially reduced household income. ${ }^{28}$ Not surprisingly, the dominant demand of regular borrowers was for their contractual debt obligation to be forgiven (35\%) or rescheduled (18\%).

Loan officers were also asked about assistance that would most help get their clients through the crisis, with results confirming the food concerns for these households: 53\% said that food donations were

\footnotetext{
${ }^{28}$ Of course, concerns about food are not limited to low-income countries; for example, the NGO Feeding America has recently surveyed food banks in the United States, and found that $98 \%$ reported increased demand for food assistance: Feeding America (2020) (see also Rampell (2020)).
} 

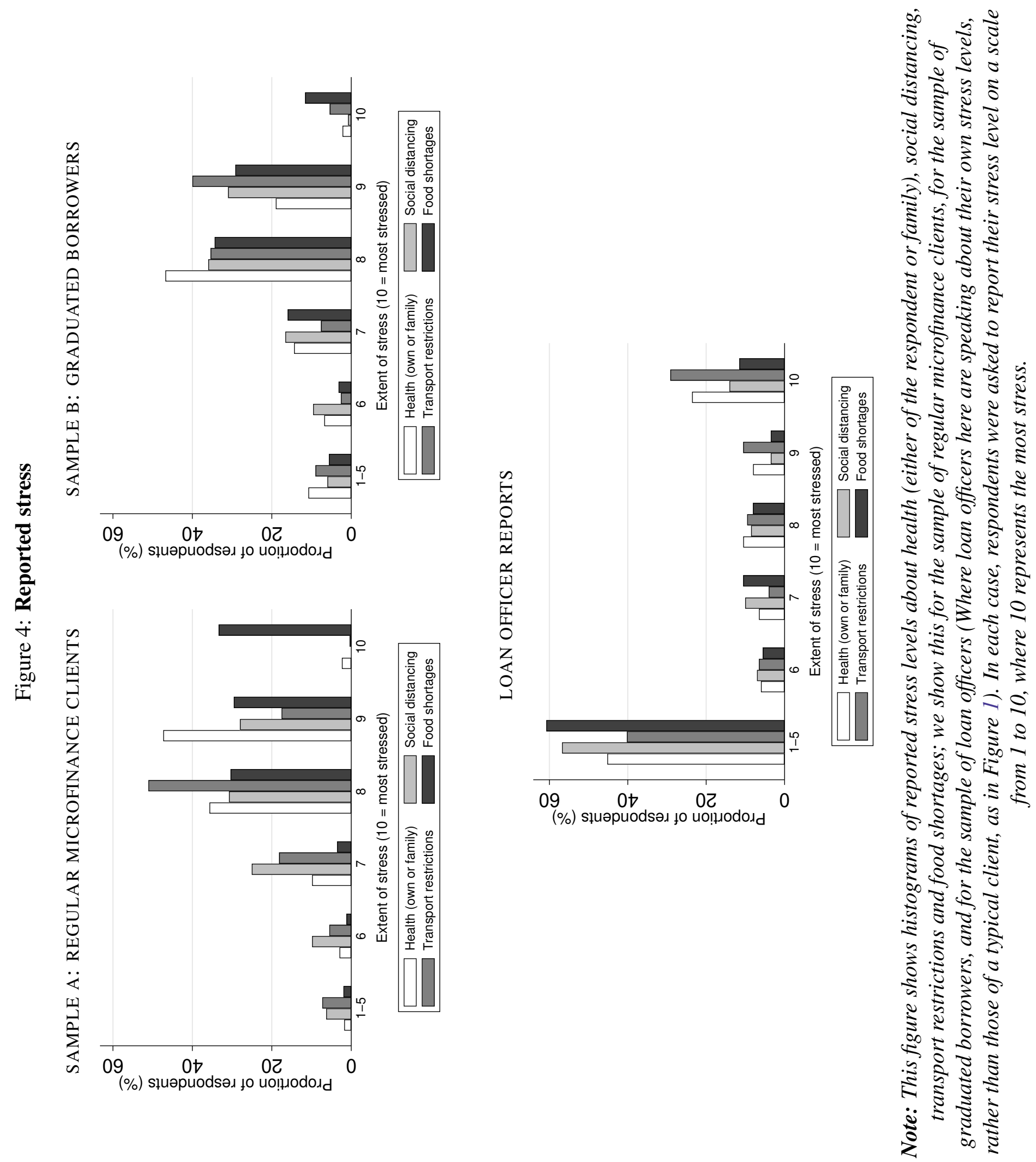
Figure 5: Recommended assistance

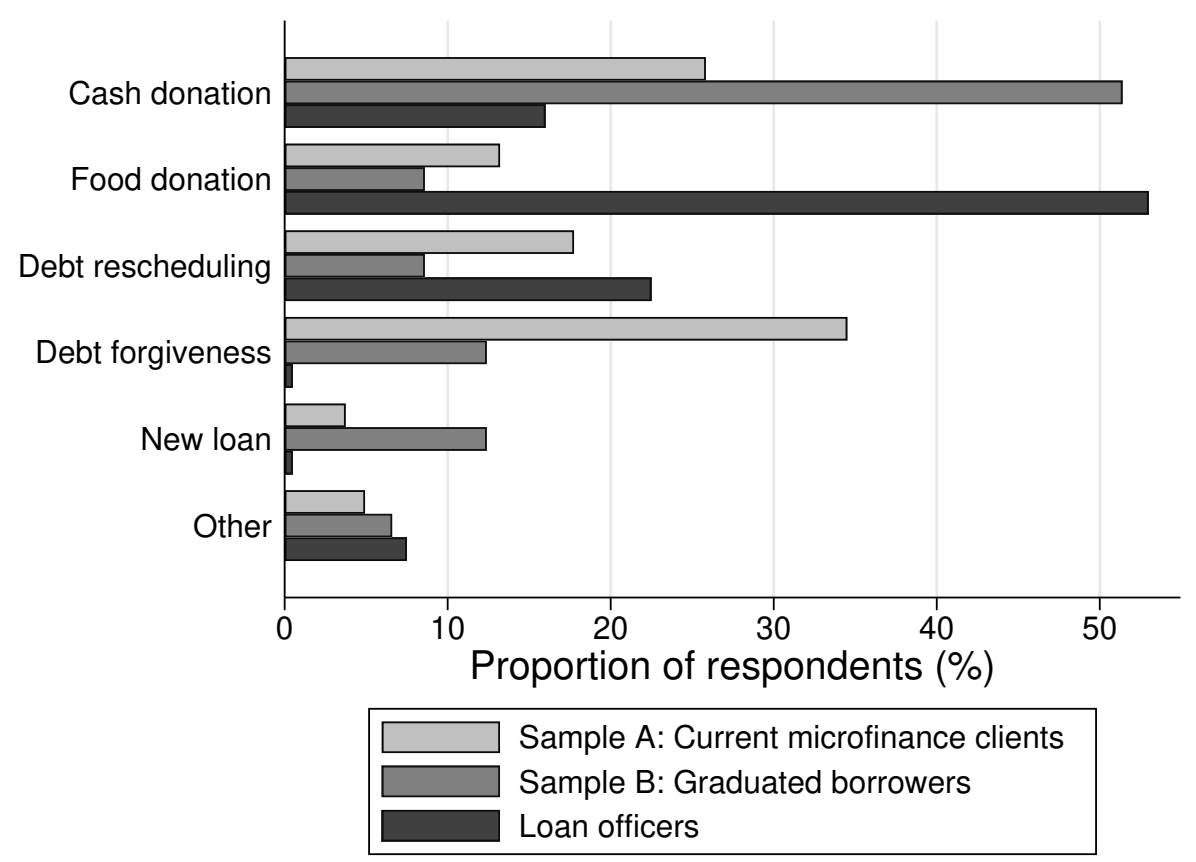

Note: This figure shows a histogram of different recommended assistance; we show this separately for the samples of regular microfinance clients, of graduated borrowers, and of loan officers.

needed the most, $16 \%$ said cash donations and $23 \%$ said debt rescheduling. Unsurprisingly, less than $1 \%$ recommended full debt forgiveness, given the impact that it would have on loan officers' own incomes. Less than $1 \%$ stated that additional loans were the solution. Interviews with senior management reveal that any new loans are expected to be used for buying food rations and meeting other short-term expenses.

Qualitatively, many enumerators received reports from the microenterprise sample that households had 'run out of money'; many reported that there was no food in their house, and many even expressed concerns about the possibility of starvation. When we conducted further qualitative follow-up interviews with microenterprise respondents, we learned that - notwithstanding these concerns - respondents were not yet reporting a food supply shortage. This is consistent with recent empirical results from Shahid (2020), showing that prices of basic food staples in Punjab markets have remained relatively steady throughout the introduction of the lockdown. This is also consistent with what was reported to 
us by the central bank. Nonetheless, clients' concerns about food shortages should remain an important concern for policy (see, for example, Dahir (2020) and Hadid (2020)). ${ }^{29}$

\subsection{Views from microfinance leaders}

We conducted our 'Survey 3' interviews - with senior leadership of MFIs and with representatives of microfinance industry associations and regulators - after the regulatory relief announced in late March. Those interviews confirmed the general sense from our interviews with clients and loan officers - in particular, reinforcing the magnitude of the shock, and the severe implications for client loan repayment. COVID-19 is, of course, not the first crisis to face Pakistani MFIs; however, as one senior representative emphasised to us, previous crises (for example, earthquakes, floods, or local conflict) were addressed through providing direct relief. Restrictions on face-to-face contact make COVID-19 qualitatively different for MFIs, both directly (through the ability to collect repayments) and indirectly (through the impact of the lockdown on economic activity). The MFI interviews presented insights on the implications of the shock at a systemic and regulatory level. It is worth emphasising that none of our respondents implied that 'better' regulation could have prevented this microfinance crisis. Nonetheless, many mentioned specific regulatory issues that they believed needed to be considered carefully as part of the response. ${ }^{30}$ We summarise some of their insights here.

\section{Heterogeneity in microfinance loan recovery policies: All MFI leaders recognised that the} lockdown had caused a dramatic reduction in clients' ability to repay outstanding loans. However, there were clear differences in loan recovery policies across MFIs. At the time of our surveys (the first two weeks of April), many MFIs had yet to communicate updated recovery policies to their clients in a consistent manner. (Indeed, as the previous section noted, only a small share of clients had been

\footnotetext{
${ }^{29} \mathrm{We}$ also asked about expectations for the duration of the lockdown; this is summarised in the appendix.

${ }^{30}$ Further, some of the 'pain points' identified by our respondents also existed before the crisis; they have been frequently mentioned to us as potentially exacerbating the adverse effects of the crisis, particularly for the most vulnerable borrowers, and it is prudent for MFIs, industry associations and regulators to consider them as part of a wider package of responses. We shared a draft of this paper with all our interviewees and received a number of positive comments, some of which suggested that the points raised by other institutions were of great interest to them and would lead them to re-assess their own policies (for example, on the compensation of loan officers).
} 
offered repayment flexibility by their loan officers.) For example, one MFI said very openly that they did not know what recovery policy they would adopt - but certainly they did not want to place any pressure on their clients during the lockdown. A different MFI reported that it was not formally cancelling clients' repayment obligations, but that it would consider options for repayment flexibility as the situation develops.

Such MFI uncertainty reflects a combination of other uncertainties - including uncertainty about the likely duration of the lockdown, and uncertainty about MFIs' own sources of funds. For example, one MFI told us that they have had discussions with their own primary lender, who agreed that further microfinance loan disbursements shouldn't happen at the moment. But that the lender was not yet in a position to approve any flexibility for the MFI. In turn, the ambiguity of MFI policy may have serious implications for client behaviour and the future credibility of MFIs; for example, one MFI reported that, in several districts across Pakistan, staff were hearing rumours from their clients - false rumours - that the Government of Pakistan had decreed that microfinance loans are now forgiven as a matter of national policy.

While many MFIs expressed a desire to move towards digital financial services and mobile banking - and to use this crisis as an opportunity to accelerate that process - a number of them mentioned a big tension in trying to 'go digital' within a business model that is so reliant upon a close physical relationship with clients. (Related to this, some MFIs were reluctant to communicate messages about the crisis to clients electronically due to low literacy levels and a risk that the message would be misunderstood as debt cancellation.)

Regulatory differences: Several MFIs expressed concern at the lack of a 'level playing field' between institutions that are often catering to a very similar client base. ${ }^{31}$ As explained earlier, NBFCs which do not take deposits - are regulated by the SECP, and MFBs are regulated by the SBP. Although

\footnotetext{
${ }^{31}$ On average, loans by MFBs have a notional value of approximately $\$ 370$, whereas those by NBFCs have a value of $\$ 144$ (Pakistan Microfinance Network, 2019).
} 
both the SECP and SBP have been active in responding to the crisis, many MFIs were concerned about a lack of consistency in the regulatory policy, and the potential impact on microfinance clients. ${ }^{32}$ In ordinary times, there may be many good reasons for drawing a regulatory distinction between bank and non-bank MFIs; in the current crisis, many MFIs - both non-bank and bank - expressed a desire for consolidation in the regulatory environment. Specifically many NBFCs expressed a strong desire to access some of the facilities available to MFBs at the SBP. In contrast, many MFBs expressed concerns at the 'light-touch' regulation of NBFCs. ${ }^{33}$

Calls for regulatory convergence are not new. For example, a report from the Pakistan Microfinance Network in the wake of the 2008-2009 financial crisis (Shah, 2011) expressed concerns about the existence of at least five types of legislative frameworks of relevance to the microfinance sector, and concerns regarding a level playing field between retail-level players.

Liquidity: Liquidity represents another important difference across MFIs. NBFCs are not permitted to take deposits, which makes them especially vulnerable to the sharp drop in revenue streams experienced with the lockdown. This is happening at the same time that their credit lines from domestic banks are at great risk of being withdrawn due to the perceived increase in risk to funding the microfinance sector (in fact, some NBFCs confirmed that they had fully drawn down their credit lines in anticipation of this). MFBs also face liquidity pressures due to the sharp decrease in their incomes - and they are not permitted to borrow directly from the central bank's 'liquidity window' ${ }^{34}$ - they are able to deal with the liquidity crunch by utilising deposits and participating in the money markets. Many MFBs told us that - although there had been some withdrawal of institutional deposits - their retail deposits had thus far been relatively stable and are well diversified (though there is clearly much uncertainty

\footnotetext{
${ }^{32}$ As mentioned, not a single respondent suggested that this caused the crisis; rather, this was a suggestion for mitigating the adverse effects of the crisis.

${ }^{33}$ In this regard, MFBs noted the very large size of some NBFCs, and the differential registration of loans with the Credit Information Bureau (CIB). In general, it seems that compliance with the CIB rules was high amongst MFBs and NBFCs, but the rules stipulate that smaller loans are not subject to reporting, which makes it difficult to know exactly how indebted borrowers are and from how many institutions they are taking smaller loans. Some concerns were also raised about the existence of two separate credit bureaus, and the desire for consolidation.

${ }^{34}$ This is only open to 'scheduled banks', such as commercial banks. MFBs reported to us that they would like to access this discount window.
} 
even in this). Most NBFCs, heavily reliant on donors and commercial loans, expressed a fear that without liquidity support - they are likely to hit serious financial problems within the coming months. Such an outcome would turn a situation of otherwise-healthy balance sheets and low risk of insolvency into a 'liquidity-induced crunch', that could lead them to lay off workers. In turn, this would lead to a vicious spiral of reduced activities, less interaction with clients, and ultimately a deterioration in the quality of their primary assets (their loan books). ${ }^{35}$

Interest payment burden: There were multiple concerns expressed by both types of MFI in relation to interest rates. The first category of concern relates to the main policy implemented to provide relief, which allows lenders to offer a deferral of principal, while continuing to collect the interest payments. While this is reasonable in theory, NBFCs in particular complained that this still involves them paying very high interest rates, at a time when their income from repayments has decreased so sharply. (Funding rates reported to us were typically in the region of KIBOR +300 basis points, which - at the start of March 2020 - amounted to $16.4 \% .{ }^{36}$ )

While this point does not generate sympathy from all quarters (it was explicitly mentioned to us on several occasions that MFIs have built up healthy profits and retained earnings in recent years), there are some other more nuanced interest-related concerns that are noteworthy. One CEO expressed serious concerns at what he described as a 'one size fits all' COVID policy that was not feasible for most NBFCs. Specifically, the policy that allows deferral of principal while continuing to collect interest may not be feasible due to the small notional amounts of the loans, which imply a very small monthly interest payment. One CEO said that it was 'a joke' for him to send a loan officer to a client to collect a 300 Rs interest payment (approximately \$1.80).

Another complaint - even more nuanced, perhaps - relates to the way that interest rates are calculated

\footnotetext{
${ }^{35}$ No respondent stated that the lack of access to a liquidity window caused their repayment crisis, nor that it would solve the problems currently faced by their clients. Rather, the MFIs' point is that it would greatly assist them in surviving the crisis to serve their clients in the future. The SECP notes that they address liquidity issues indirectly through Circular 9 - which has allowed PMIC to defer principal repayments and reschedule loans of MFIs.

36 'KIBOR' is the Karachi Interbank Offered Rate. The one-year KIBOR was 13.36 on 2 March.
} 
on a standard microfinance loan. Loans typically involve monthly repayments, which are calculated using a 'declining balance' structure. Unlike a flat-rate calculation, which leads to the same monthly interest payment (since the interest rate is always applied to the nominal value of the loan), a declining balance loan involves a fixed total monthly payment, with a changing composition of interest and principal. While such a calculation method results in lower required payments from clients, ${ }^{37}$ and is simple to understand, it requires a relatively big administrative burden if one were to request just the interest portion of the loan each month. MFIs also reported that this becomes practically infeasible when payments are collected through agents, such as telecoms agents, who are often used and are only familiar with collecting the same monthly payment from a client.

To summarise, many MFIs stated that they are not able to collect the interest on their loans due to the complexity and cost - though they are obliged still to pay the interest on their own borrowings from commercial banks. Finally, for those few microfinance institutions that issued bullet-payment agricultural loans, there was a concern expressed at the accrual of a large amount of interest over the period of deferral, and the ability of clients to pay off their deferred principal and accrued interest in a year's time. ${ }^{38}$

Incentive issues for loan officers: As previously discussed, qualitative questions from our loan officer surveys suggest that many are under substantial emotional stress. The heterogeneity in MFIs' responses to the crisis - some clearly deferring all payments; others leaving it ambiguous - also ampli-

\footnotetext{
${ }^{37}$ Our survey suggests that most microfinance institutions are using declining balance payment structures, with the notable exception of agricultural loans that typically have a 'bullet' repayment at maturity, tailored to the agricultural harvest cycle. In contrast, MFI Transparency (2011) reports that 70\% of microfinance loans in Africa involve interest calculated on a flatrate basis, which obviously has big implications in such a crisis - i.e. if just the principal deferral is allowed, the interest payment (calculated on the full notional loan amount) is still very large. MFI Transparency (2011) explains: "The flat rate calculation method has become prevalent in markets where there is a lack of transparency and the mechanisms to facilitate it. The flat rate allows financial institutions to advertise costs that are nearly twice as high as they appear. To most borrowers, especially those with minimal financial education, the flat rate seems cheaper. Once one institution begins to calculate their prices this way it is difficult for others to compete using a declining balance rate that appears higher but may actually be less expensive. For example, a lender using declining balance calculation must set the interest rate as high as $56.3 \%$ per year to collect the same amount of total interest payment as another one who is using a $36 \%$ per year flat rate. Without policy or standards in place to prevent this, institutions must resort to non-transparent practices in order to be competitive."

${ }^{38}$ Those MFIs for whom this applied stated that the accruing of interest was necessary for them and reflected the cost of keeping the loans active and staying in touch with clients.
} 
fies the pressures faced by loan officers, and can create some perverse incentives for behaviour. This can manifest in several ways - for example, loan officers who anticipate that their MFI is about to collapse might continue to request payments from clients, which they then keep for themselves. One $\mathrm{CEO}$ at a prominent institution reported his amazement that loan officers he had previously dismissed for fraud, and reported to the authorities, were later observed to be working in senior positions at other microfinance institutions. There were many suggestions made for a 'staff information bureau', similar to a consumer credit bureau, which registers staff who are offering financial products to microfinance clients and records if there were previous instances of misconduct. This was seen as necessary even in good times - and especially so now, given the serious vulnerability of many borrowers and the pressures that loan officers are under during the crisis. Less dramatically, loan officers who anticipate that they are about to lose their jobs may face substantial 'hidden action' incentives to deviate from company policy on loan collection. It was frequently reported to us that such incentive problems are not unusual even in normal times - when, for example, one MFI might 'poach' a successful loan officer from another MFI, in order to gain their portfolio and local knowledge. However, such risks are likely to be exacerbated in a context where, as now, there is a substantial liquidity risk for some MFIs, and substantial confusion about MFI policy. ${ }^{39}$

\section{Demand for financing instruments with greater risk-sharing properties: One of the most} consistent desires expressed by all MFIs was for the provision of better risk-sharing instruments, which would allow them to manage this current crisis and would increase the resilience of the sector in the face of future crises, including climate-related and agricultural shocks. While many MFIs mentioned better risk-sharing in the instruments that provide them with capital, and some suggested that clients

\footnotetext{
${ }^{39}$ Many of our enumerators highlighted a concern that loan officers only expressed to them informally while conducting theinterviews - that they will be losing a large share of their own incomes. Many MFIs structure their loan officer salaries to include high-powered incentives: a bonus based on repayment rates and new disbursements. Since new disbursements have almost completely shut down, and repayment rates are collapsing, a large share of loan officer income is disappearing,which can very problematic on many levels. These issues have arisen before. In particular, two reports of the Pakistan Microfinance Network (Azia, 2015; Shakoor, 2018) have previously documented a number of challenges that loan officersface even in normal times: a very large number of clients per loan officer (over 300 on average), pressure to be the driver of the organisation's growth, the problem of a low basic salary and challenges of high-powered incentives. High loan officer turnover is also mentioned, and the lack of a 'proper procedure' for becoming a loan officer, which echoes concerns raised in our interviews about the risk of negative loan officer behaviours and the need for a staff information bureau.
} 
also need to be provided with better risk-sharing in terms of products they are offered, the overwhelming call by MFBs in particular was for a credit guarantee scheme (CGS). Such a scheme would offer risk sharing to lenders by taking a portion of the lenders' losses in the event of loan defaults. A CGS can provide risk mitigation either by sharing losses on a pari passu basis between the CGS and the lender, and / or with the CGS covering a fixed percentage of the first loss. Our interviews with senior representatives at the State Bank of Pakistan revealed that such a CGS had previously existed in Pakistan, supported by the UK Department for International Development. ${ }^{40}$

Given how many MFIs strongly expressed a need for such a CGS to help them through the crisis and support individuals who need to rebuild post-crisis, it seems like a good moment to re-evaluate a CGS. For example, the Irish government has recently launched a COVID-19 credit guarantee scheme to encourage lending to SMEs by offering an $80 \%$ guarantee to banks against losses on qualifying loans to eligible SMEs, for which the banks pay a $0.5 \%$ premium to cover the cost of the guarantee. ${ }^{41}$ Some of the MFI CEOs we spoke with said that they were currently willing to pay as much as 4 to 5\% for such a guarantee programme, which could have a dramatic effect on their ability to take more risk and provide loans to businesses looking to re-capitalize and re-invest following the lockdown. ${ }^{42}$

\footnotetext{
${ }^{40}$ The Microfinance Credit Guarantee Facility, involving both first-loss and pari passu loss sharing, was meant to facilitate wholesale funding to the microfinance industry under a risk-sharing mechanism. However, with the establishment of PMIC, the facility had to be shut down on the donor's request to allow the market to develop. Further, a CGS is being offered by the SBP for Micro, Small Medium Enterprises (MSME) through participating financial institutions, which include both MFBs and commercial banks. We have been informed that this facility will shortly be spun off into the Pakistan Credit Guarantee Company (PCGC), which is being established to facilitate affordable risk sharing solutions for the MSME sector.

${ }^{41}$ For details, see https://dbei.gov.ie/en/What-We-Do/Supports-for-SMEs/Access-to-Finance/ SME-Credit-Guarantee-Scheme/. The World Bank also has detailed guidelines for best practice in the design of public guarantee schemes, and addresses way in which moral hazard can be addressed on the parts of both lenders and SMEs: http://documents.worldbank.org/curated/en/576961468197998372/Principles-for-publi c-credit-guarantee-schemes-for-SMEs.

${ }^{42}$ One may argue that the middle of an unprecedented crisis is not the right time to ask those most affected by the crisis about the optimal policy in a post-crisis world or, more specifically, to ask what they would pay for a CGS (because they may overestimate the risk of another crisis and may overpay for insurance). Our interviews with microfinance leaders indicate a high level of sophistication and well-reasoned thinking about possible solutions; further, even if such leaders overestimate the value of a CGS, the fact that they mention this as a way to help them recover from the crisis and provide them with greater confidence in disbursing capital to clients who need it (for example, those in sectors not as adversely affected by the crisis, such as agriculture), and to those businesses that are expected to bounce back quickly, suggests that a CGS is worth considering as a policy option.
} 


\section{Conclusion}

A central feature of the economic lives of the poor is the combination of low incomes, volatility and unpredictability (Collins et al., 2009; Morduch and Schneider, 2017). Effectively coping with a volatile and unpredictable income is made easier by ready access to financial services, but the small transactions begotten by low incomes combined with fixed administrative costs make it exceedingly difficult for the market to provide those services. That has historically been the rock on which attempts to bring low-income households into the formal financial services market have crashed.

Serving such households requires business model compromises that lower the costs and risks for providers. History reveals that the costs of those compromises eventually come due. For instance, early rural credit cooperatives lowered costs of customer acquisition and monitoring by relying on the strong, local social networks among farmers. However, that made the cooperatives vulnerable to local shocks and limited their ability to intermediate and scale - ultimately dooming many of them either through insolvency or competition (Roodman, 2012; Caprio, 2016; Wadhwani, 2016).

The modern microfinance movement seemed to have escaped this trap. Over the course of the last 40 years, hundreds of millions of people have gained access to formal financial services. There is a meaningful microfinance sector in more than a hundred countries (MIX, 2019). While a large literature has explored the customer-facing innovations (see Armendáriz and Morduch (2010) for an overview), such as group liability, standardized products and dynamic incentives, equally important to the success of modern microfinance is innovations in access to capital - especially the ability to access capital beyond that of the customers served. The combination of innovations to lower the cost and risk of serving low-income customers and of accessing capital from outside of low-income communities has allowed microfinance to cope relatively easily with a number of serious crises of the type that had often devastated financial service providers to low-income households in the past.

For example, while the Asian Financial Crisis and the 2008 Financial Crisis both heavily disrupted 
global capital markets, they had relatively little impact on the day-to-day economic lives of the microfinance clientele - and thus most microfinance institutions could weather the storm in capital markets. Meanwhile, disruptions to the basic business of microfinance - such as the 'No Pago' movement in Nicaragua, the Andhra Pradesh crisis or the Ebola epidemic - caused significant disruption in specific geographies, but the industry was able to bounce back quickly because of ready access to national and global capital markets, development finance institutions, bilateral and multilateral aid agencies and philanthropic funders (Ogden, 2011; Rozas, 2011; Guérin et al., 2015; Chakma et al., 2017).

The COVID-19 pandemic is different from the crises that have come before. It disrupts both the clientfacing and the capital-facing sides of microfinance simultaneously. MFIs are suffering from both a lack of repayments and a lack of access to capital and liquidity from funders. What our surveys have documented in Pakistan seems to be playing out in most countries - and thus we are seeing a crisis for the industry as a whole.

The profound crisis, sufficient to make it highly likely that a significant number of MFIs globally will not survive, presents both the necessity and the opportunity to reconsider the innovations and compromises that have shaped the modern microfinance movement. That reconsideration is vital to guide policy responses to the present crisis and its aftermath-in Pakistan and elsewhere. Here, as in the introduction, we frame the reconsideration around six points, designed to stimulate discussion in the microfinance policy community.

First, the industry must reconsider how microfinance is used by most of its customers. We are far from the first to point out the mismatch between the standard microcredit loan and the rhetoric of business investment (Field et al., 2013). But that rhetoric still shapes conceptions of microfinance; the current crisis demonstrates the frailty of this argument. For most clients, microcredit is primarily a tool for managing liquidity, for households and microenterprises to match their volatile cashflows to their 
money management needs (Rutherford, 2000). ${ }^{43}$ The concerns of the microfinance CEOs we surveyed were not consistent with those of investment banks but with those of markets that depend on liquidity - the kind of financial markets (such as overnight lending) that central bank authorities in the United States and Europe stepped in to backstop first. Recognizing that microfinance is primarily about managing liquidity has many implications, especially for regulation and oversight.

Second, the idea that non-deposit-taking institutions could be exempted from prudential regulation because customers would not be hurt by failure or insolvency (and perhaps could even be helped) is highly questionable if the primary use of the product is managing liquidity. When investment loans become unavailable, growth is certainly a casualty and recession is likely. But when sources of liquidity dry up, consequences can be much more severe in a much shorter time frame and with devastating effects for both sides of a market. That is a different rationale for prudential regulation of microfinance and its role in the economy of lower-income households and microenterprises. While microfinance institutions are quite diverse, there may be some common need for regulation and supervision due to the similar roles the institutions play in the financial lives of their customers, and the overlap in the customer base. Specifically, the surveys point to significant near-term and, absent action to provide future access to financial services including borrowing, long-term suffering of most microfinance customers. That is a powerful argument for regulators and central bank authorities to quickly expand their efforts at stabilizing the financial sector to include all forms of microfinance. Emergency liquidity facilities and recapitalization must be considered to allow MFIs of whatever stripe to forbear or forgive current loans and be in a position to extend liquidity management products when the pandemic is under control.

Third, now is the time to extend regulation and supervision beyond financial oversight to consumer protection. While such regulation would not have prevented the current crisis, the depth and seri-

\footnotetext{
${ }^{43}$ There are, of course, households and microenteprises that use microcredit to invest in business assets, as demonstrated in a number of studies - but those same studies show that the majority of clients use funds in ways that do not materially increase revenues or profits; clients often spend primarily on inventory or other working capital rather than on capital investments that increase their profitability (Banerjee et al., 2019; Karlan et al., 2016; Meager, 2019).
} 
ousness of the crisis requires it sooner rather than later to protect customers from even more harm. ${ }^{44}$ The MFI CEOs we surveyed shared concerns about the behaviour of field staff; loan officers and customer reports showed they were right to be concerned. When a product plays such a large role in poor households' financial lives, it behooves governments to ensure that those households are protected from exploitation by the providers of that product. Governments should consider taking consumer protection principles developed within the industry as voluntary guidelines and making them mandatory regulations. Such discussions should begin with how to handle recovery from the current crisis. Many governments, like Pakistan, have imposed moratoriums on repayment - some with forbearance on interest, others not. Regardless, as survey participants noted, it is unclear whether borrowers will ever be able to fully repay these loans, especially absent new lending. What does consumer protection and responsible lending look like in the aftermath of a pandemic? Letting individual MFIs decide for themselves may not produce optimal outcomes for the lenders or for the borrowers (see point six below for more discussion of this issue).

Fourth, the global microfinance business model may need to be significantly rethought - and additional innovation may be needed. While it's clear that MFIs are facing a liquidity crunch, and absent bailouts may quickly face insolvency, it is unclear what happens next. Even if bailouts are forthcoming, capital markets may be much more wary of investing in MFIs now that there is experience of how quickly normal operating procedure can turn into insolvency. Given that there is considerable uncertainty as to how the pandemic will play out, including possible recurrences of COVID-19, or of other epidemics or pandemics (there have now been three novel coronavirus epidemics in 17 years), there should also be uncertainty that the way microfinance has been funded for the last 40 years will remain viable. On the customer side, additional regulation and supervision imposes costs. There is a clear trade-off between the amount of regulation and who gets served (Cull et al., 2011) - more regulation means higher costs, which means that the most marginalized and poorest (read, most expensive to serve) will likely find that they are no longer part of the target market of many institutions (which may in turn struggle to find

\footnotetext{
${ }^{44}$ The Securities and Exchange Commission of Pakistan regulates microfinance institutions with an eye to consumer protection and ensuring that customers have a form of redress. The challenge is to extend such regulation to more countries and to ensure that regulations are adequately enforced.
} 
funding if they can't make the case they are serving the most excluded). Along with the rhetoric about microcredit financing investment, the rhetoric that there are 'no tradeoffs' in investing in microfinance, and that the model is self-sustaining and subsidy is not needed, will likely need to be jettisoned (Cull et al., 2017). To name just one part of the global funding mechanism, loan guarantees to microfinance institutions have been marketed to social investors and philanthropists as risk-free uses of their capital (O'Neil, 2015). Clearly MFIs and microfinance investment vehicles are going to have to update their appeals and expected risk-adjusted returns.

Fifth, most of the focus on innovation in microfinance in the last decade has been about the potential for digital financial services and mobile money (particularly) to lower operating costs and expand access to formal financial services. The current crisis illustrates just how far there is to go before digital financial services change operating procedures in the industry (with obvious heterogeneity from country to country). Deploying technological solutions is capital intensive - both in terms of financial and of human capital. That's why the leaders in digital financial services tend to be either well-funded existing corporations with a steady revenue stream (like mobile network operators) or fintechs with access to large amounts of risk capital (see Tala and Branch, two prominent digital lenders, as examples). The hope had been that MFIs could 'ride the rails' of digital financial infrastructure without having to invest substantially themselves. The current crisis illustrates that this has not happened. In our survey, MFI CEOs were wary of digital communications with customers; on top of illiteracy, there is ample room for misinterpretation of messaging - for good reasons, and we suspect there concerns would be widely shared around the world. Few MFIs are positioned to transition from face-to-face transactions to digital. If anything, digital financial services have allowed disintermediation of MFIs as new digital-only entrants take market share with considerable controversy over consumer protection (Izaguirre et al., 2018; MSC, 2019; Gwer et al., 2019; Faux, 2020). In the aftermath of the pandemic, this trend could accelerate. MFIs' capital, again both financial and human, is likely to be very constrained and will need to be devoted to lending operations to restore positive cash flow before MFIs can begin to invest in a digital transition. Will investors have the stomach to fund technology investment, or will they prefer to allocate capital to fintechs? Even if the MFIs were able to gain access to the capital necessary to 
make the transition, they would need all of their (poor, excluded) customers to make the transition as well before they were able to do away with face-to-face transactions. In the meantime, it's possible that fintechs or other players will siphon away MFIs' best customers, leaving the MFIs to serve the least profitable and least digital-savvy segments of the market, putting them further under pressure as they try to recover.

Sixth, and finally, two of the most important, but intangible assets built up by microfinance are at risk. The first is trust. MFIs, with exceptions, of course, have built up a great deal of trust with their customers by following rules-based processes and providing reliable services in environments where both are often lacking (Collins et al., 2009; Roodman, 2012). Without collective action - from MFIs, regulators and supervisors, and investors - that trust could be destroyed by the present crisis. Deposit-taking institutions are obviously of key concern. But as many MFIs struggle to secure a future, their behaviour in terms of treatment of customers, especially their ability to monitor the behaviour of loan officers and field staff, will play a large role in whether the trust that has been built up remains intact. The possibility that customers receive conflicting messages from different parts of an MFI or from different MFIs serving their community or from regulators or politicians is extremely high. All microfinance institutions need to communicate clearly, set fair expectations, and work with customers with an eye to long-term outcomes, even as the short-term situation remains so dire. There is a significant role for regulators and investors to play in ensuring that the industry does not deplete its most valuable long-term asset - trust - while trying to survive the short- and medium-term crisis. The second is organizational capital-the collective stock of knowledge about how to successfully lend to low-income customers. This is yet another reason to motivate regulators and governments to bail out MFIs whether they have been in their purview prior to the crisis or not. If that organizational capital is lost due to institutions becoming insolvent, it will be costly to rebuild and would likely delay recovery in the communities that microfinance has served.

The surveys we conducted in Pakistan, supported by similar work in many other contexts, reveals that the pandemic is indeed a crisis for microfinance without precedent in the modern industry's history. 
What emerges from the other side will likely vary considerably from country to country and context to context, but if the current pandemic continues for long, whatever emerges will likely be substantially different from what we have seen over the last 40 years.

\section{References}

Abi-Habib, M. and Yasir, S. (30 March, 2020). For India's Laborers, Coronavirus Lockdown Is an Order to Starve. The New York Times. https: / /www. nytimes.com/2020/03/30/world /asia/coronavirus-india-lockdown.html, accessed 31 March, 2020.

Adams-Prassl, A., Boneva, T., Golin, M., and Rauh, C. (2020). Inequality in the Impact of the Coronavirus Shock: Evidence from Real Time Surveys. Working paper.

Afridi, F., Dhillon, A., and Roy, S. (23 April, 2020). How has Covid-19 Crisis Affected the Urban Poor? Findings from a Phone Survey. Ideas for India. https://www. ideasforindia.in /topics/poverty-inequality/how-has-covid-19-crisis-affected-theurban-poor-findings-from-a-phone-survey.html.

Armendáriz, B. and Morduch, J. (2010). The Economics of Microfinance. MIT press.

Azia, S. (2015). Loan Officers' Voices: Perspectives and Lessons from the Foot Soldiers. Report of the Pakistan Microfinance Network: https://www.pmn.org.pk/publications/Loan 200fficers\%20Voices.pdf.

Banerjee, A., Breza, E., Duflo, E., and Kinnan, C. (2019). Can microfinance unlock a poverty trap for some entrepreneurs? Working Paper 26346, National Bureau of Economic Research.

Bartik, A. W., Bertrand, M., Cullen, Z. B., Glaeser, E. L., Luca, M., and Stanton, C. T. (2020). How are small businesses adjusting to covid-19? early evidence from a survey. Working Paper 26989, National Bureau of Economic Research.

Basharat, A. and Sheikh, Z. (2019). The How and the Why of Microfinance Lending Rates. Pakistan Microfinance Network, Micronote 42: https: / / pmn.org.pk/the-how-the-why-of-mi crofinance-lending-rates/.

Bick, A. and Blandin, A. (2020). Real Time Labor Market Estimates During the 2020 Coronavirus Outbreak. Working paper.

Caprio, Jr, G. (2016). Financial history and economic development: Pitfalls and promises. In Cassis, Y., Grossman, R. S., and Schenk, C. R., editors, The Oxford Handbook of Banking and Financial History, pages 62-84. Oxford University Press. 
Chakma, H., Coppel, E., Diallo, A., Dubitsky, R., and Whisson, I. (July 2017). Financial inclusion and resilience: How brac's microfinance program recovered from the west african ebola crisis. Global Delivery Initiative Case Study: https: / /www. findevgateway . org/case-study/201 7/07/financial-inclusion-and-resilience-how-bracs-microfinance-p rogram-recovered-west.

Collins, D., Morduch, J., Rutherford, S., and Ruthven, O. (2009). Portfolios of the Poor: How the World's Poor Live on \$2 a Day. Princeton University Press.

Cull, R., Demirgüç-Kunt, A., and Morduch, J. (2011). Does regulatory supervision curtail microfinance profitability and outreach? World Development, 39(6):949-965.

Cull, R., Demirgüç-Kunt, A., and Morduch, J. (2017). The Microfinance Business Model: Modest Profit and Enduring Subsidy. World Bank Economic Review, 32(2):221-244.

Dahir, A. L. (22 April, 2020). 'Instead of Coronavirus, the Hunger Will Kill Us.' A Global Food Crisis Looms. The New York Times. https: / / www. nytimes.com/2020/04/22/world/afric a/coronavirus-hunger-crisis.html,accessed22April,2020.

Dai, R., Hu, J., and Zhang, X. (2020). The Impact of Coronavirus on China's SMEs: Findings from the Enterprise Survey for Innovation and Entrepreneurship in China. Center for Global Development Note: https://www.cgdev.org/sites/default/files/impact-coronavirus -chinas-smes-findings-from-esiec.pdf.

Duflo, E. and Banerjee, A. (29 March, 2020). A Prescription for Action: Nine Steps After the Next 21 days. The Indian Express.

Faux, Z. (12 February, 2020). Tech startups are flooding kenya with apps offering high-interest loans. Bloomberg Businessweek.

Feeding America (8 April, 2020). Feeding America Network Faces Soaring Demand, Plummeting Supply Due to COVID-19 Crisis. https: / / www. feedingamerica.org/about-us/pr ess-room/soaring-demand-plummeting-supply.

Field, E., Pande, R., Papp, J., and Rigol, N. (2013). Does the classic microfinance model discourage entrepreneurship among the poor? experimental evidence from india. American Economic Review, 103(6):2196-2226.

Garlick, R., Orkin, K., and Quinn, S. (2019). Call Me Maybe: Experimental Evidence on Frequency and Medium effects in Microenterprise Surveys. The World Bank Economic Review. https: //doi.org/10.1093/wber/lhz021.

Guérin, I., Labie, M., and Servet, J.-M. (2015). The Crises of Microcredit. University of Chicago Press.

Gwer, F., Odero, J., and Totolo, E. (2019). Digital credit audit report: Evaluating the conduct and practice of digital lending in kenya. Kenya FSD report: https: / / fsdkenya.org/publica tion/digital-credit-audit-report-evaluating-the-conduct-and-prac tice-of-digital-lending-in-kenya/. 
Hadid, D. (2020). Pakistan Has A Plan To Keep Millions From Going Hungry During Shutdown. Will It Work? NPR: www.npr.org/sections/goatsandsoda/2020/04/14/831753354 /pakistan-has-a-plan-to-keep-millions-from-going-hungry-during-s hutdown-will-it-w.

Hale, T. and Webster, S. (2020). Oxford COVID-19 Government Response Tracker. https : / / ww w.bsg.ox.ac.uk/research/research-projects/oxford-covid-19-govern ment-response-tracker.

Izaguirre, J. C., Kaffenberger, M., and Mazer, R. (25 September 2018). It's time to slow digital credit's growth in east africa. https://www.cgap.org/blog/its-time-slow-digital-cr edits-growth-east-africa.

Karlan, D., Osman, A., and Zinman, J. (2016). Follow the money not the cash: Comparing methods for identifying consumption and investment responses to a liquidity shock. Journal of Development Economics, 121:11-23.

Khawar, H. (14 April, 2020). Save Lives or Save Livelihoods? Express Tribune, Pakistan.

Meager, R. (2019). Understanding the average impact of microcredit expansions: A bayesian hierarchical analysis of seven randomized experiments. American Economic Journal: Applied Economics, 11(1):57-91.

MFI Transparency (2011). Flat vs Desclining Balance Interest Rates. MFI Transparency Pricing Fundamental: https://www.mftransparency.org/wp-content/uploads/2012/0 5/MFT-BRF-205-EN-Flat-versus-Declining-Balance-Interest-Rates-Wh at-is-the-Difference-2011-09.pdf.

MIX (October 2019). Mix market:mfi company metadata. https: / / datacatalog . worldban k.org/dataset/mix-market.

Morduch, J. and Schneider, R. (2017). The Financial Diaries: How American Families Cope in a World of Uncertainty. Princeton University Press.

MSC (September 2019). Making digital credit truly responsible. https://www. microsave. ne t/wp-content/uploads/2019/09/Digital-Credit-Kenya-Final-report.p df.

Ogden, T. (10 June, 2011). The Microfinance Contagion Scenario. Harvard Business Review.

Ogden, T. and Bull, G. (2020). COVID-19: How Does Microfinance Weather the Current Storm. https: / / www.financialaccess.org/blog/2020/3/26/covid-19-how-does -microfinance-weather-the-current-storm.

O’Neil, S. K. (10 June 2015). Loan guarantees and financial inclusion in the developing world. http s://www.cfr.org/blog/loan-guarantees-and-financial-inclusion-dev eloping-world.

Pakistan Microfinance Network (2019). Pakistan Microfinance Review 2018. https : / / pmn . org . pk/pakistan-microfinance-review-2018/. 
Pakistan Microfinance Network (2020). Microwatch (Issue 54): A Quarterly Update on Microfinance Outreach in Pakistan. https://pmn.org.pk/microwatch-issue-54/.

Rahman, H. Z. and Matin, I. (16 April, 2020). Livelihoods, Coping, and Support during the Covid-19 Crisis. https://bigd.bracu.ac.bd/wp-content/uploads/2020/04/Liveliho ods-Coping-and-Support-during-COVID-19-Crisis.pdf.

Rampell, C. (3 April, 2020). The next threat: Hunger in America. The Washington Post.

Roodman, D. (2012). Due Diligence: An Impertinent Inquiry into Microfinance. Brookings Institution Press.

Rozas, D. (2011). Weathering the storm: Hazards, beacons, and life rafts. Center for Financial Inclusion Publication 11: https: / / centerforfinancialinclusionblog.files.wordpr ess.com/2011/07/weathering-the-storm_center-for-financial-inclus ion_final.pdf.

Rutherford, S. (2000). The Poor and Their Money. Oxford India Paperbacks.

Rutherford, S. (2020). Hrishipra Daily Diaries: Corona virus. https://sites . google.com/s ite/hrishiparadailydiaries/home/corona-virus.

Shah, M. (2011). Regulating Pakistan's Non-Bank Microfinance Institutions. Report of the Pakistan Microfinance Network: https://www.pmn.org.pk/publications/Regulating $20 \mathrm{P}$ akistans\%20Non\%20Bank:20Microfinance\%20Institutions.pdf.

Shahid, A. (27 February, 2020). Two Coronavirus Cases Confirmed in Pakistan. Pakistan Today.

Shakoor, A. (2018). Salary Trends in Microfinance Industry of Pakistan. Report of the Pakistan Microfinance Network: https://www.pmn.org.pk/publications/Salary20 Trend s\%20in\%20Microfinance 20 Industry $200 f \% 20$ Pakistan.pdf.

Wadhwani, R. D. (2016). Small-Scale Credit Institutions: Historical Perspectives on Diversity in Financial Intermediation. In Cassis, Y., Grossman, R. S., and Schenk, C. R., editors, The Oxford Handbook of Banking and Financial History, pages 191-214. Oxford University Press. 


\section{Appendix}

\subsection{Further details on SECP and SBP responses}

\subsubsection{Securities and Exchange Commission}

On 30 March 2020, the Securities and Exchange Commission of Pakistan (SECP) issued a notification $^{45}$ allowing flexibility in complying with international financial reporting standards for Non-bank Microfinance Companies (NBFCs). The was followed the next day by a circular (SC/NBFC-81/ 2020) that aimed to facilitate the process of non-banking financial institutions rescheduling the loans of their borrowers as a result of COVID-19. Specifically, the policy permits all NBFCs, including Non-bank Microfinance Companies (NBFCs), to (amongst other things):

(i). Defer the repayment of the loan principal amount for one year, upon a written request from the borrower up until 30 June 2020, provided that the borrower will continue to service the interest payments (officially referred to as 'mark-up'). The NBFC is permitted to decline the request, but must provide the reason, and reply within 15 working days of the request. If they allow this, it will not affect the credit history of the borrower and will not be reported as restructuring in the Credit Information Bureau (ECIB).

(ii). Those borrowers who cannot service the interest payments or repay the principal within one year can request a rescheduling within 90 days of their loans being overdue for microfiannce loans, and will be 'treated as regular and reported in the ECIB accordingly'.

This was distributed to all CEOs of NBFCs, NBFCs, the Pakistan Microfinance Network (PMN), and the non-bank financial institution and Modaraba Association.

\subsubsection{The State Bank of Pakistan}

On 26 March 2020, the State Bank of Pakistan's (SBP) Agricultural Credit \& Microfinance Department issued a circular describing the regulatory relief given to dampen the effects of COVID-19 on Microfinance Banks (MFBs). ${ }^{46}$ This includes: ${ }^{47}$

(i). MFBs are permitted to defer the payment of loan principal by one year for their borrowers who request it in writing by 30 June 2020; however, payments of interest (officially referred to as 'mark-up') will continue to be due. MFBs must convey their decision withing 15 days of the request, and if they refuse must provide reasons to the borrower. MFBs must submit details of deferments granted to borrowers to the SBP on a weekly basis, and the deferment will not affect the credit history of the obligor nor will it be reported in the ECIB as restructuring.

(ii). Borrowers who are not able to service the interest or need deferral for more than one year can request this and be granted it if the rescheduling / restructuring is done within 90 days of the loans being due. Such arrangements will be treated as 'regular' and "reported in the CIB accordingly", i.e. such deferment will not be considered a default. In the case of MFBs, approved rescheduling will not report it as "restructuring" in the ECIB, provided the rescheduling is completed before the financing facility is 90 days past due.

${ }^{45}$ Notification reference SC/NBFC-191/IFRS-9/2020.

${ }^{46}$ AC\&MFD Circular Letter No. 1 of 2020.

${ }^{47}$ Further details of SBP measures undertaken in response to COVID-19 are available at: http://www. sbp.org.pk/C orona.asp. 
(iii). The above only applies to loans that became non-performing after 15 February 2020.

\subsection{Expectations about the duration of the lockdown}

We asked microenterprise owners how long they thought it would be before the lockdown ended, and how long it would be before business returned to normal. The most striking result is a great amount of uncertainty: $68 \%$ of microenterprise owners stated that they had absolutely no idea at all how long it will be before the lockdown ends; $26 \%$ said that it would end in less than a month (which is consistent with the official government policy $)^{48}$, and $6 \%$ thought that it would last between one and three months. Fewer than $1 \%$ thought that it would extend beyond three months. In terms of business normalisation, responses largely mirrored the expectations of the lockdown: $44 \%$ thought that business would return to normal within a month, $52 \%$ thought that it would take one to three months, and fewer than $3 \%$ thought that it would take more than three months to return to normal.

Loan officers, in contrast, expressed less uncertainty about the likely duration of the lockdown: only $11 \%$ said they had no idea, $63 \%$ thought that the lockdown would end within a month, and $26 \%$ thought that it would persist between one and three months. This may reflect a higher level of certainty, or simply access to greater information than microenterprise clients. Turning to perceptions of a return to normality, responses indicate a 'lag', and are consistent with their previous predictions for expected repayment rate on their loan portfolio: only $20 \%$ thought that things would return to normal within a month, $66 \%$ thought that it would take between one and three months, and $9 \%$ thought that it would take between three and six months.

\subsection{Robustness of sales measures}

One possible concern with Figure 1 is that the week immediately prior to the lockdown may have been an unusual one - either because customers were deciding prematurely to stay home, or because customers were accelerating purchases in anticipation of the lockdown. In Figure 6, we compare sales in the week before the lockdown to sales in the week preceding that; we find that the relationship was remarkably stable, with the best fit lying close to the 45-degree line.

\footnotetext{
${ }^{48}$ At the time of the survey, the lockdown was officially due to continue for one more week.
} 
Figure 6: Effect on sales

\section{SAMPLE A: REGULAR MICROFINANCE CLIENTS}

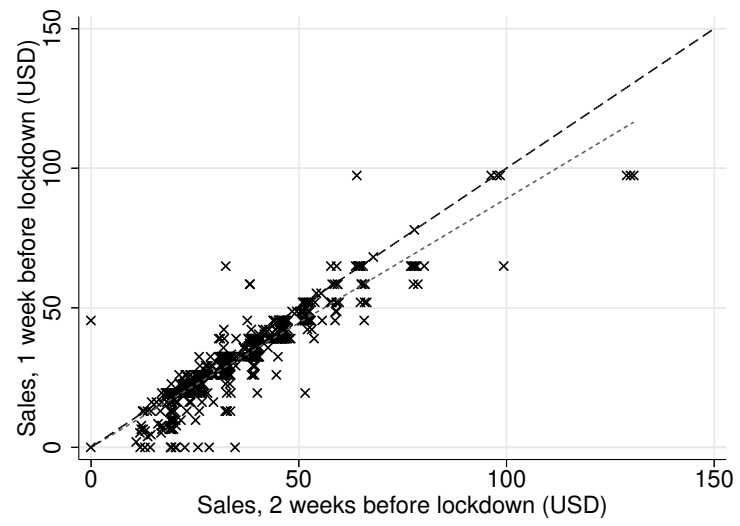

SAMPLE B: GRADUATED BORROWERS

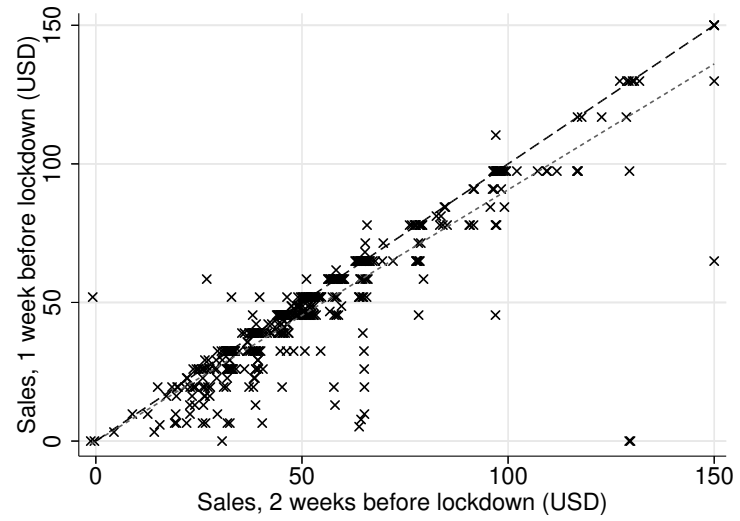

Note: This figure compares microenterprise sales two weeks before and one week before the lockdown: for the sample of regular microfinance clients, and for the sample of graduated borrowers. We use US\$, with the exchange rate of 1 March (i.e 1 US\$ $=154$ Pakistani rupees). Each figure shows a 45-degree line and an OLS regression line (imposing a zero intercept). For clarity, we top-censor the data at US\$150, and apply a minimal random jitter in the $x$-axis. 